\title{
Does the implant-abutment interface interfere on marginal bone loss? A systematic review and meta-analysis
}

\section{Enéias Carpejani ROSA(a) \\ Tatiana Miranda DELIBERADOR(a) \\ Tuanny Carvalho de Lima do NASCIMENTO(a) \\ Cibele Cândida de Almeida KINTOPP(a) \\ Juliana Shaia Rocha ORSI(a) \\ Letícia Maíra WAMBIER(a) \\ Sharukh Soli KHAJOTIA ${ }^{(b)}$ \\ Fernando Luis ESTEBAN FLOREZ ${ }^{(b)}$ \\ Carmen Lucia Mueller STORRER ${ }^{(a)}$}

(a) Universidade Positivo, School of Health Sciences, Graduate Program in Dentistry, Curitiba, PR, Brazil.

(b) The University of Oklahoma Health Sciences Center, Division of Dental Biomaterials, Department of Restorative Sciences, Oklahoma City, Oklahoma, USA.

Declaration of Interests: The authors certify that they have no commercial or associative interest that represents a conflict of interest in connection with the manuscript.

\section{Corresponding Author:}

Carmen Lucia Muller Storrer

E-mail:carmen.storrer@up.edu.br;

carmen.storrer@gmail.com

https://doi.org/10.1590/1807-3107bor-2019.vol33.0068

Submitted: June 6, 2019

Accepted for publication: June 13, 2019

Last revision: June 17, 2019
Abstract: The objective of this systematic review was to compare the conical internal connection (IC) with the external hexagonal connection $(\mathrm{EH})$ on the occurrence of marginal bone loss $(\triangle \mathrm{MBL})$. Different databases were used to carry out the selection of the elected studies. The studies were judged according to the risk of bias as "high", "low" and "unclear" risk. For the meta-analysis we included only studies that could extract the data of $\triangle \mathrm{MBL}$, survival rate (SR) and probing depth (PD). No statistically significant differences were found for $\triangle \mathrm{MBL}$ data at one, three- and five-year survival rates between implant connections ( $p<0.05)$, however statistically significant differences were found for PD between EH and IC implants (1-year follow-up) -0.53 [ $95 \% \mathrm{CI}-0.82$ to $-0.24, \mathrm{p}=0.0004]$. This present systematic review demonstrated that there are no significant differences between IC and $\mathrm{EH}$ implants for both $\triangle \mathrm{MBL}$ and $\mathrm{SR}$ at 1,3 e 5 years after functional loading, although better PD values were observed for implants pertaining to the IC connections. Considering the high heterogeneity, more well-delineated, randomized clinical trials should be conducted.

Keywords: Dental Implants; Dental Implant-Abutment Design; Systematic Review.

\section{Introduction}

Great scientific evidence (in vitro, in vivo and clinical trials) has demonstrated that modern oral rehabilitation techniques, based on the use of endosseous dental implants, have recently allowed for the attainment of highly osseointegrated restorations displaying remarkable initial esthetic and mechanical properties..$^{1-5}$ Numerous studies, however, have shown that these types of rehabilitations are typically associated with significant bone loss over the course of their service lives. Because of that, marginal bone loss has been considered one of the most important criteria to define the clinical success of dental implants.

According to a consensus reached at the International Congress of Oral Implantology (ICOI), a successful dental implant may display at radiographic assessment, physiological bone losses (i.e., saucerization) smaller than $2.0 \mathrm{~mm}$ after the installation of the prosthesis ${ }^{6}$ (within the first year) and additional $0.2 \mathrm{~mm}$ for each subsequent year of activity. ${ }^{7,8}$ Even though saucerization may adversely impact the position of the 
gingival margin and consequently the expected esthetic results, saucerization has been shown to be necessary for the re-establishment of the biological space surrounding dental implants.,10 Thus, the localization of the implant-pillar interface (micron-sized gap) is of fundamental relevance for the success of dental implants because it has been previously demonstrated to act as a contributing factor for the occurrence of peri-implant-related marginal bone loss. ${ }^{10,11,12}$

The implant developed by Brånemark displayed an external hexagon $(\mathrm{EH}$, height $=0.7 \mathrm{~mm})$. Such design should work as a locking system to prevent unwanted rotation and to facilitate the surgical placement of implants. ${ }^{13}$ This implant design, however, favors the concentration of high amount of force over the screw and leads to micromovement generation, that combined, typically results in the subsequent critical failure of the implants due to mechanical and biological reasons. ${ }^{14,15}$ To solve this problem, new connection designs were developed, that resulted in a classification division between tapered and non-tapered and internal and external abutments. ${ }^{16}$

The internal tapered connection (IC) provides a juxtaposition (by attrition) and superior mechanical stability that eliminates unwanted rotation and pillar loosening. ${ }^{17}$ In addition, the tapered interface decreases the distance between the pillar and the implant body that results superior seals and decreased risk of infiltration. These factors combined, have been shown to hider tissue inflammation (both soft and hard), periimplantitis and marginal bone loss..$^{18,19,20}$ Even though image assessments have significantly improved over the last few years, and tomographic analyses provide very precise $\triangle \mathrm{MBL}$ results, periapical radiographies, standardized by the parallelism method, continues to be the most commonly used technique to measure the time-dependent evolution in $\triangle \mathrm{MBL}^{21,22,23}$

A few clinical studies investigating $\triangle \mathrm{MBL}$ in $\mathrm{EH}$ and IC implants, using radiographic analysis, have found that after 1 year of follow-up, EH implants displayed the lowest levels of $\triangle \mathrm{MBL} \cdot{ }^{24,25}$ Other studies, however, have contradicted these results by reporting data suggesting that higher $\triangle \mathrm{MBL}$ levels were found for EH implants when compared to IC implants $\left(1^{26}\right.$ and $3^{27}$ years of follow-up). The lack of consensus regarding the impact of connection design on $\triangle \mathrm{MBL}$ is demonstrated further in the literature by studies that have reported that no statistical differences in $\triangle \mathrm{MBL}$ could be found for both $\mathrm{EH}$ and IC dental implants ( $2^{28}$ and $5^{29}$ years of follow-up). Thereby, and taking into consideration the observation of strongly contradictory results, it was decided to perform a systematic review and meta-analysis of follow-up clinical studies ( 1 year or more) investigating the impact of implant connection designs (either IC or $\mathrm{EH})$ on $\triangle \mathrm{MBL}$.

\section{Methodology}

The present study was conducted according to the Preferred Reporting Items for Systematic Review and Meta-analysis Protocols (PRISMA-P) ${ }^{30}$ and it was performed at the Universidade Positivo, UP, Curitiba, Paraná, Brazil from June to September of 2018. The research protocol utilized was then registered at the International Prospective Register of Systematic Review (PROSPERO) under the protocol number CRD42018090991.

\section{Research strategy}

The research strategy was based on the PICOS acronym where $(\mathrm{P})$ stands for the population investigated (edentulous patients with dental implants), (I) stands for the types of intervention (Morse taper internal connection), (C) stands for intervention comparison (external connection), (R) stands for the results assessed [primary outcome: marginal bone loss ( $\triangle \mathrm{MBL})$; secondary outcome: probing depth and implant survival rates] and (S) stands for study design (randomized clinical trials). The strategy was also based on the utilization of Mesh terms to allow for further standardization of the search.

\section{Data bases}

PubMed/MEDLINE, Scopus, Cochrane Library, Web of Science, Biblioteca Brasileira em Odontologia (BBO) and Centro Latino-Americano e do Caribe de Informação em Ciências da Saúde (LILACS) were searched (Figure 1). Table 1 illustrates both the 
Mesh- and free-terms used during the execution of the present study. Other data bases such as the System for Information on Gray Literature (SIGLE), Periódicos de bancos de dados e teses da CAPES and ProQuest Dissertations and Theses Full Text were also used to strengthen the power of the search strategy. References from primary literature were manually checked for other relevant publications in PubMed, where no restrictions regarding language or data were considered. Finally, repositories containing results from on-going clinical studies such as Clinical Trials (www.clinicaltrials.gov), Rebec (www.ensaiosclinicos. gov.br), Current Clinical Trials (www.controlled- trials.com) and The International Clinical Trials Registry Platform (http://www.who.int/ictrp/en/) were also searched regarding PICOS of the present systematic review.

\section{Inclusion and exclusion criteria}

Follow-up (at least 1 year) randomized clinical trials (RCT) that investigated the impact of implant-pillar connection designs (either EH or IC) on the evolution of peri-implant $\triangle \mathrm{MBL}$ in edentulous patients (male and female) subjected to implant-based oral rehabilitation techniques in maxilla or mandibula with any type of functional loading (either immediate, premature

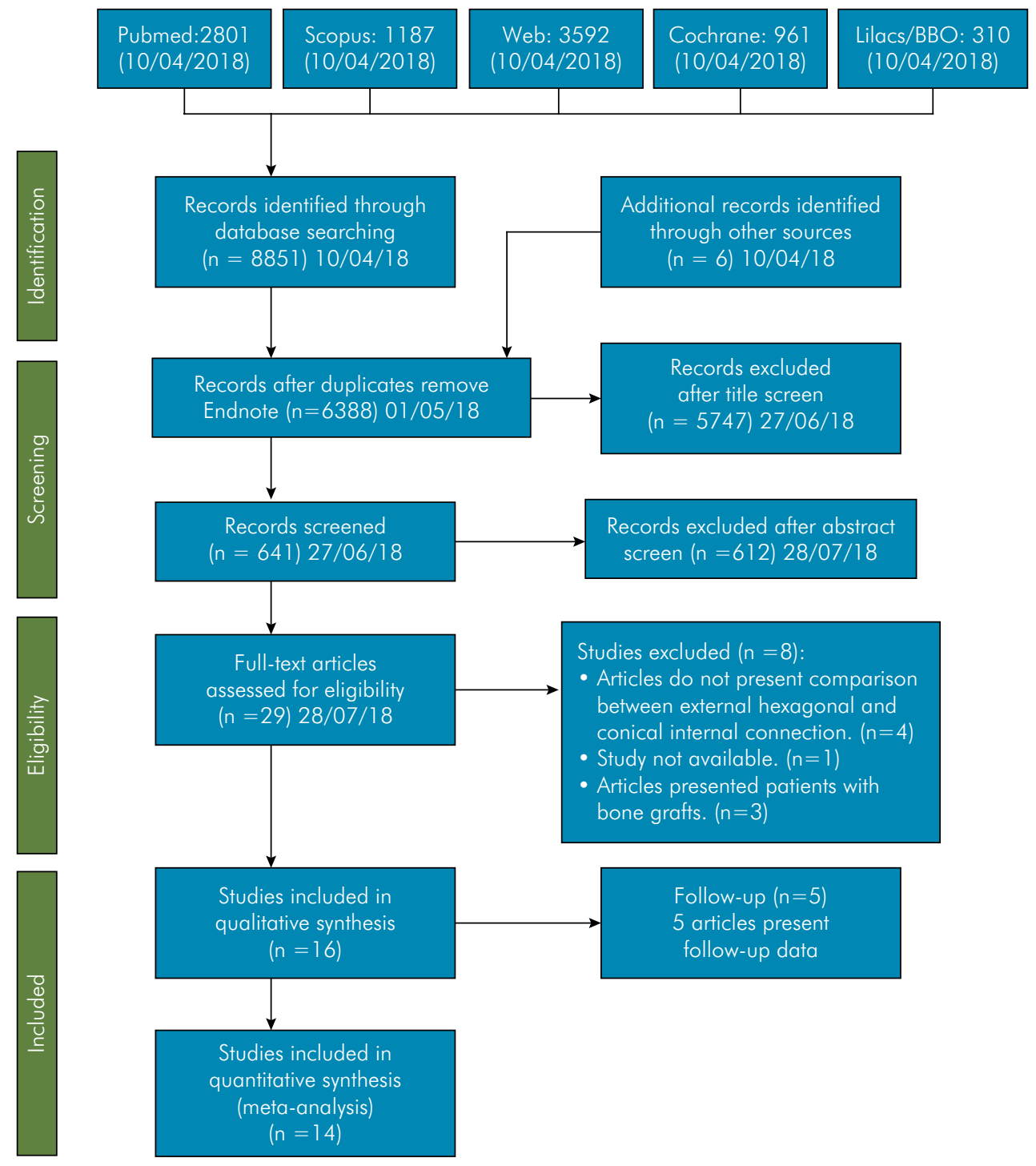

Figure 1. Present study's flow diagram. 
Table 1. Systematic review search strategy.

\begin{tabular}{|c|c|}
\hline \multicolumn{2}{|l|}{ Scopus $=1187(10 / 04 / 2018)$} \\
\hline $\begin{array}{l}\text { \# } 1 \text { (TITLE-ABS-KEY (mandible) OR TITLE-ABS-KEY } \\
\text { (maxilla) OR TITLE-ABS-KEY ("jaw edentulous") } \\
\text { OR TITLE-ABS-KEY ("maxillary bone?") OR } \\
\text { TITLE-ABS-KEY ("mandible bone?") OR } \\
\text { TITLE-ABS-KEY ("mandibular bone?") OR } \\
\text { TITLE-ABS-KEY ("Maxillary implant?")) }\end{array}$ & $\begin{array}{c}\text { \#2 (TITLE-ABS-KEY ("dental implant?") AND TITLE-ABS-KEY ("dental implant } \\
\text { abutment design") OR TITLE-ABS-KEY ("dental abutment?") OR TITLE-ABS-KEY (“Cone } \\
\text { Morse") OR TITLE-ABS-KEY ("short dental implants") OR TITLE-ABS-KEY ("Morse taper") } \\
\text { OR TITLE-ABS-KEY ("internal connection") OR TITLE-ABS-KEY ("external connection") } \\
\text { OR TITLE-ABS-KEY ("implant abutment connection") OR TITLE-ABS-KEY ("implant } \\
\text { abutment connection")) }\end{array}$ \\
\hline \multicolumn{2}{|l|}{ \#1 AND \#2 AND \#3 } \\
\hline \multicolumn{2}{|l|}{ Web of Science-3592 (10/04/2018) } \\
\hline$\# 1$ & $\# 2$ \\
\hline $\begin{array}{l}\text { TS }=(\text { Mandible) OR TS=(Maxilla) OR TS=("jaw } \\
\text { edentulous") OR TS=("maxillary bone?") OR } \\
\text { TS=("mandible bone?") OR TS=("mandibular } \\
\text { bone\$") OR TS=("maxillary implant\$") }\end{array}$ & 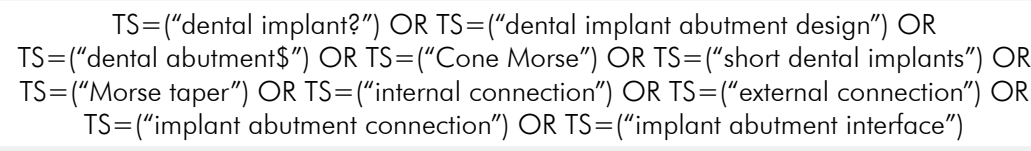 \\
\hline \multicolumn{2}{|l|}{ \#1 AND \#2 } \\
\hline \multicolumn{2}{|l|}{ Lilacs and $\mathrm{BBO}=310(10 / 04 / 2018)$} \\
\hline $\begin{array}{l}\text { \# } 1 \text { (MH: mandible OR MH:maxilla OR } \\
\text { "jaw edentulous" OR "maxillary bones" OR } \\
\text { "mandible bones" OR "mandibular bones" OR } \\
\text { "maxillary implants" OR "arcada edêntulas" OR } \\
\text { "osso maxilar" OR "ossos da mandíbula" OR } \\
\text { "osso mandibular" OR "implantes maxilares" } \\
\text { OR "arcada edéntula" OR "hueso maxilar" } \\
\text { OR "huesos del mandíbula" OR "hueso del } \\
\text { mandibular") }\end{array}$ & $\begin{array}{l}\text { \#2 (MH:" dental implants" OR MH: "dental implant abutment design" OR } \\
\text { MH: "dental abutments" OR "Cone Morse" OR "short dental implants" OR "morse } \\
\text { taper" OR "dental implant" OR "internal connection" OR "external connection" OR } \\
\text { "implant abutment connection" OR "implant abutment interface" OR "implantes } \\
\text { dentários" OR "implante dental curto" OR "implante dental" OR "projeto do implante } \\
\text { dentário pivô" OR "dente suporte" OR "conexão interna" OR "conexão externa" OR } \\
\text { "interface implante pilar" OR "conexão implante pilar" OR "implantes dentales" OR } \\
\text { "implantes dentales cortos" OR "pilares dentales" OR "diseño de implante dental pilar" } \\
\text { OR "implante pilar dental con interfase" OR "implante pilar dental con conexión" OR } \\
\text { "conexión interna" OR "conexión externa") }\end{array}$ \\
\hline
\end{tabular}

\# 1 AND \#2 AND \#3

Cochrane Library $=961 \quad(10 / 04 / 2018)$

\# $4 \mathrm{MeSH}$ descriptor: [Mandible] explode all trees \#3 MeSH descriptor: [Maxilla] explode all trees mandible:ti,ab, kw or maxilla:ti,ab, kw or "jaw edentulous":ti,ab,kw or "maxillary bones":ti,ab,kw or \# 1"mandible bones":ti,ab, kw (Word variations have been searched)

\#2 mandibular next bones:ti,ab,kw or maxillay next implants:ti,ab,kw (Word variations have been searched)

\#5 \#4 or \#3 or \# 1 or \#2

MeSH descriptor: [Dental Implants] explode all trees. $\mathrm{MeSH}$ descriptor: [Dental Implant-Abutment Design] explode all trees $\mathrm{MeSH}$ descriptor: [Dental Abutments] explode all trees dental next implant:ti,ab, kw or "dental implant abutment design":ti,ab, kw or dental next abutments:ti,ab, kw or "cone morse":ti,ab,kw or "short dental implants":ti,ab,kw (Word variations have been searched) "morse taper":ti,ab,kw or "internal connection":ti,ab, kw or "external connection":ti,ab, kw or "implant abutment connection":ti,ab, kw or "implant abutment interface":ti,ab,kw

(Word variations have been searched) \#6 or \#7 or \#8 or \#9 or \#10

\#5 AND \# 11

or delayed) and prosthetic rehabilitations. Pilot, retrospective, in vitro (laboratorial and animal models) or clinical studies comprised of patients with selected risk factors (i.e., diabetes, bruxism, pregnancy, chemoand radiotherapy) or that had been subjected to bone grafts were excluded from the present study.

\section{Selection of publications and data collection process}

The ENDNOTE ${ }^{\circledR}$ software (Philadelphia, USA) was used to select all the manuscripts included in the present study. After initial selection, the compiled library was checked for duplicates and manuscripts were further triaged based on a dynamic and focused reading of abstracts that took into consideration the inclusion and exclusion criteria previously described. This process was performed independently by two trained and calibrated examiners, authors, reviewers (ECR and TL). Eventual discrepancies between them were solved by a third independent, trained and calibrated examiner (CMS). A data collection chart was used to standardize the extraction of data that was used for the manufacturing of two results tables (Tables 2 and 3). 


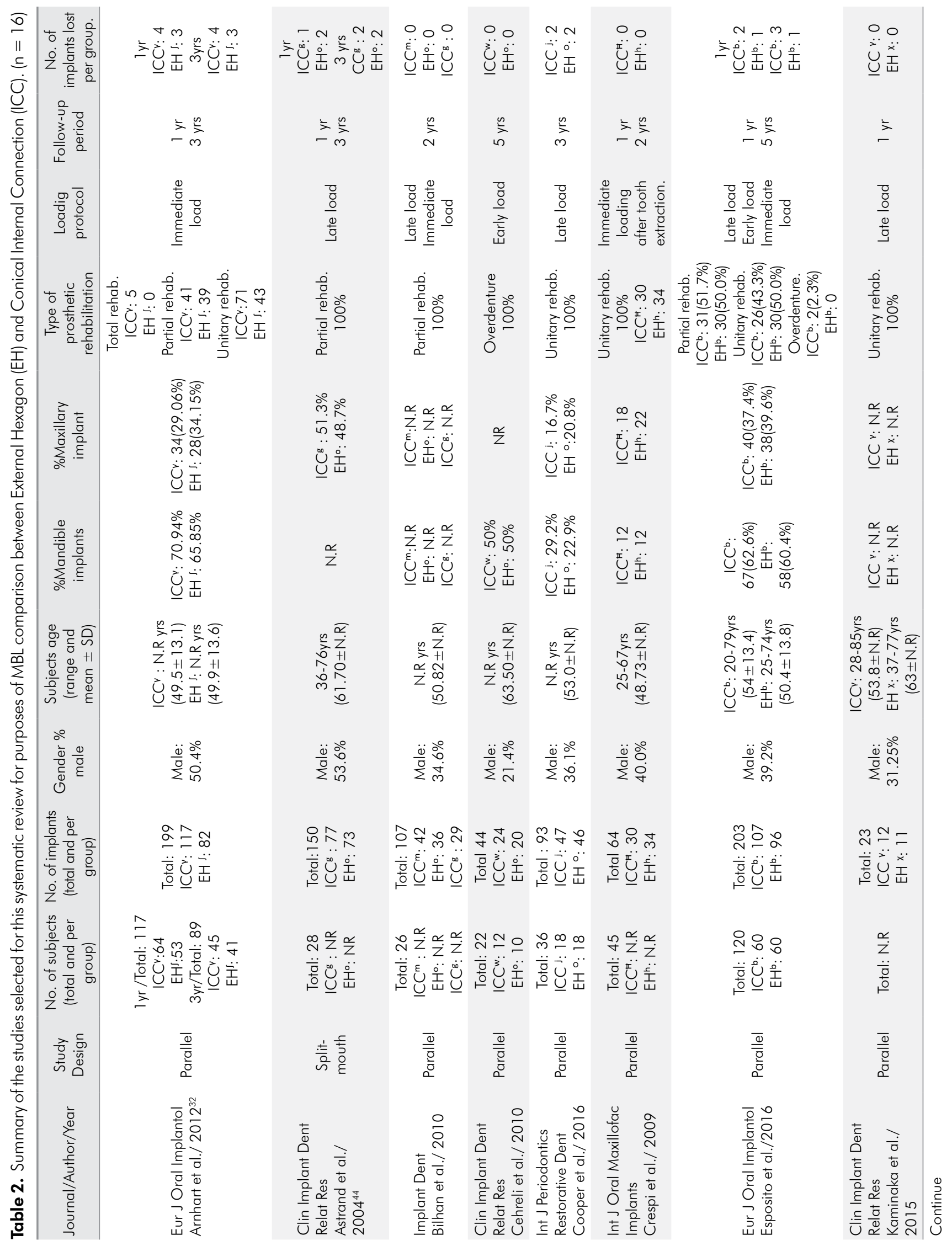




\begin{tabular}{|c|c|c|c|c|c|c|c|}
\hline $\begin{array}{l}00 \\
\ddot{\ddot{U}} \ddot{\theta} \\
\underline{\underline{t}}\end{array}$ & 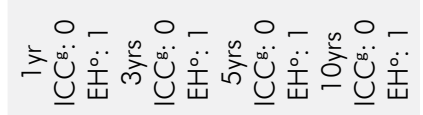 & 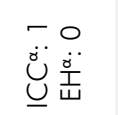 & 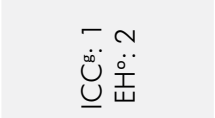 & $\begin{array}{l}\overline{\ddot{u}}= \\
\underline{u} \\
\underline{u} \\
\end{array}$ & 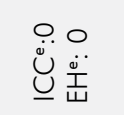 & $\begin{array}{l}\circ \circ \\
\ddot{\ddot{U}} \ddot{x} \\
\underline{\underline{x}}\end{array}$ & 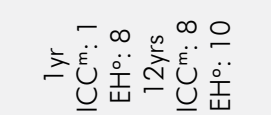 \\
\hline$\stackrel{2}{\Sigma}$ & 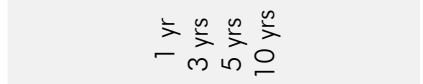 & 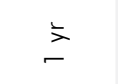 & $\stackrel{n}{\frac{n}{2}}$ & $\Sigma$ & $\Sigma$ & $\begin{array}{l}\sum \sum_{m}^{\infty} \\
-m\end{array}$ & 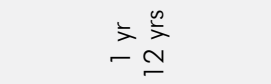 \\
\hline $\begin{array}{l}\frac{\overline{0}}{0} \\
\frac{0}{0} \\
\frac{0}{G}\end{array}$ & $\begin{array}{l}\frac{0}{0} \\
\frac{0}{0} \\
\frac{0}{9}\end{array}$ & 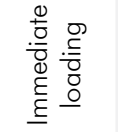 & $\begin{array}{l}\frac{0}{0} \\
\frac{0}{0} \\
\frac{0}{9}\end{array}$ & $\begin{array}{l}\frac{0}{0} \\
\frac{0}{0} \\
\frac{0}{9}\end{array}$ & 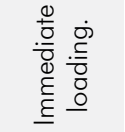 & $\begin{array}{l}\frac{0}{0} \\
\frac{0}{0} \\
\frac{0}{9}\end{array}$ & $\begin{array}{l}\frac{0}{0} \\
\frac{0}{0} \\
\frac{0}{9}\end{array}$ \\
\hline 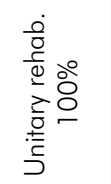 & 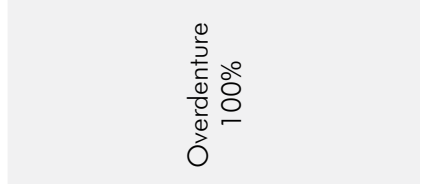 & 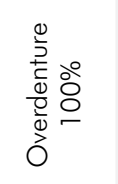 & $\begin{array}{l}\frac{\dot{0}}{0} \\
\frac{\overline{0}}{0} \\
\frac{0}{0} \\
\frac{0}{0} \\
\frac{0}{0}\end{array}$ & 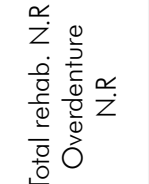 & $\begin{array}{l}\frac{\dot{0}}{0} \\
\frac{0}{0} \frac{0}{0} \\
\frac{0}{0} \\
\frac{0}{0} \\
\frac{0}{0}\end{array}$ & 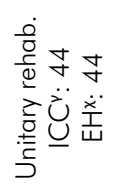 & $\begin{array}{l}\frac{\dot{0}}{0} \\
\frac{\bar{c}}{0} \\
\frac{0}{0} \\
\frac{0}{0} \\
\frac{0}{0}\end{array}$ \\
\hline 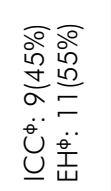 & $\stackrel{\alpha}{z}$ & $\stackrel{\alpha}{Z}$ & $\stackrel{\alpha}{z}$ & $\stackrel{\alpha}{z}$ & $\stackrel{\alpha}{z}$ & $\stackrel{\propto}{z}$ & 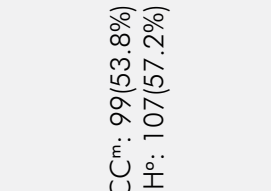 \\
\hline 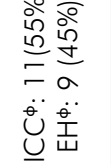 & 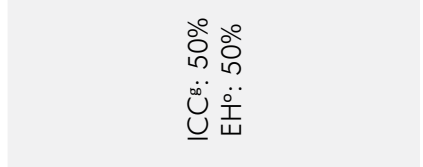 & 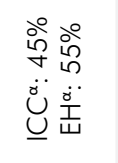 & 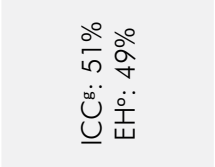 & $\stackrel{\alpha}{z}$ & 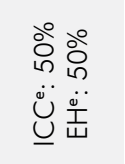 & 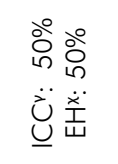 & 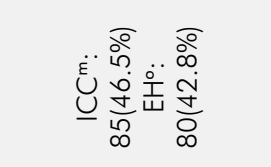 \\
\hline 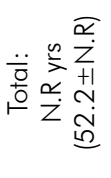 & 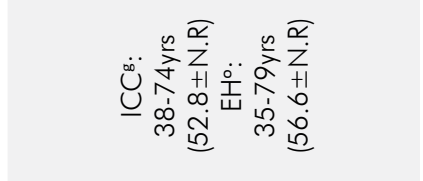 & 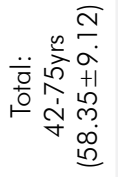 & 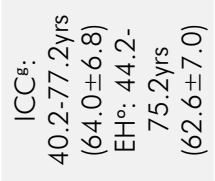 & $\begin{array}{l}\sum_{z}^{\infty} \\
\frac{\alpha}{z} \\
z\end{array}$ & 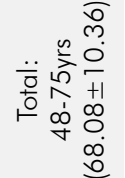 & 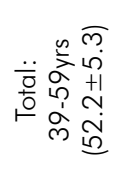 & 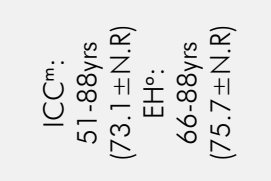 \\
\hline ฉ̊ & ஓे & ळ్ & ه్రి & & ڤัे & $\circ \circ$ & $\ddot{0} \ddot{0}$ \\
\hline$\frac{\ddot{\omega}}{\sum^{0}}$ & $\frac{\ddot{\theta}}{\sum^{0}}$ & $\frac{\ddot{\theta}}{\sum^{0}}$ & $\frac{\ddot{\omega}}{\sum^{0}}$ & $z$ & $\frac{\ddot{\omega}}{\sum^{0}}$ & $\sum^{0} \dot{z}$ & $\sum^{0} \bar{\sigma}$ \\
\hline 유유 & 공 & 우요 $\mathbb{N}$ & ๑ & 온 & $\stackrel{\sim}{\simeq \simeq}$ & $\infty_{\infty}^{\infty} \underset{\forall}{\forall}$ & $\widetilde{N} \underset{\infty}{0} \underset{\infty}{\infty}$ \\
\hline 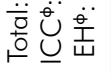 & 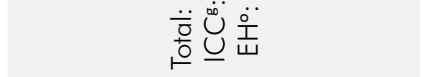 & 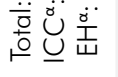 & 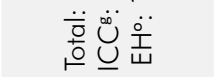 & 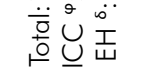 & 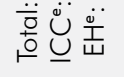 & 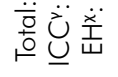 & 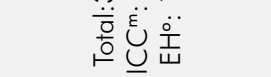 \\
\hline 유유 & ৪্লি প্লি & $\stackrel{N}{a}=$ & 유유 & $\stackrel{\sim}{\sim} \stackrel{\alpha}{z} \underset{z}{\alpha}$ & $\cong \stackrel{a}{Z} \stackrel{\alpha}{Z}$ & ॠे ले ఫ్ల & 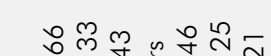 \\
\hline 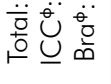 & 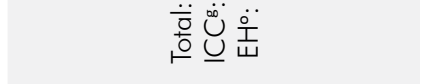 & 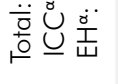 & 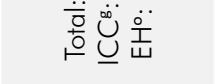 & 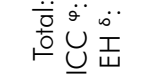 & 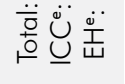 & 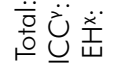 & 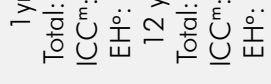 \\
\hline 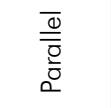 & $\frac{\bar{\Phi}}{\overline{\overline{0}}}$ & $\begin{array}{l}\bar{\Phi} \\
\frac{\overline{\bar{\sigma}}}{\overline{0}} \\
0\end{array}$ & $\begin{array}{l}\overline{\frac{0}{\sigma}} \\
\frac{\bar{\sigma}}{\alpha} \\
\square\end{array}$ & 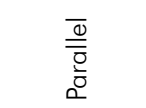 & 音亭 & 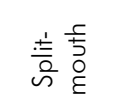 & 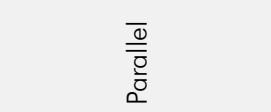 \\
\hline 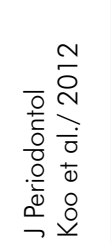 & 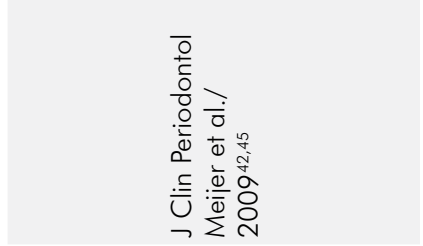 & 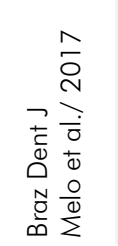 & 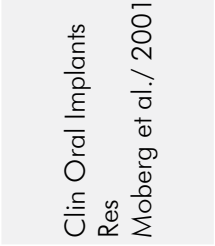 & 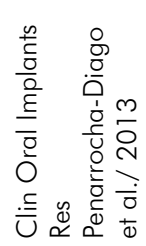 & 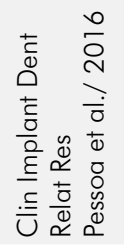 & 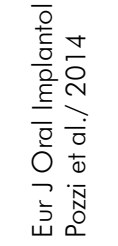 & 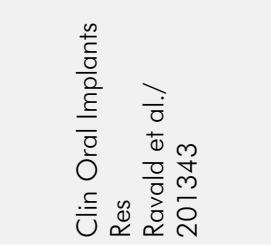 \\
\hline
\end{tabular}




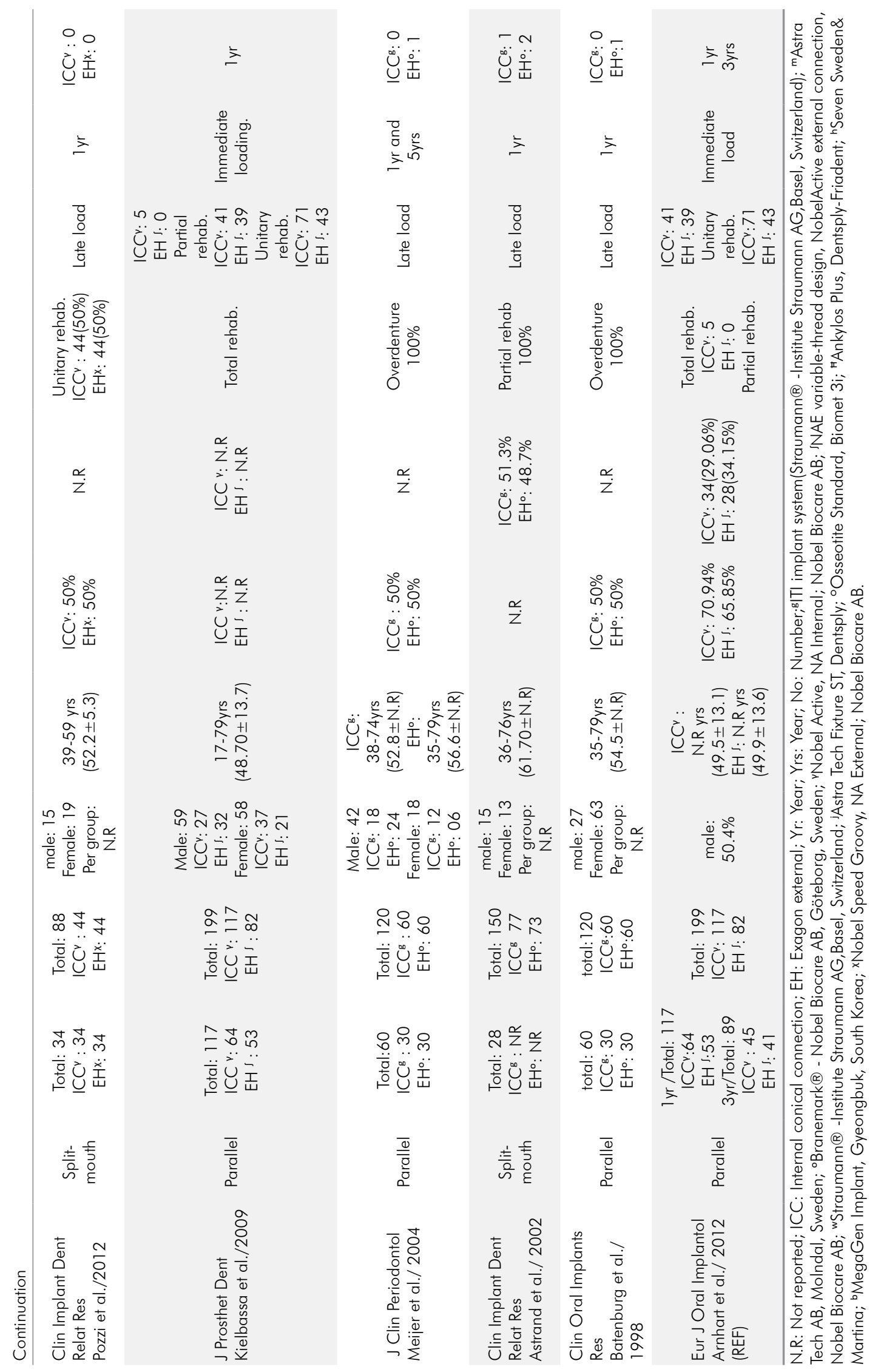




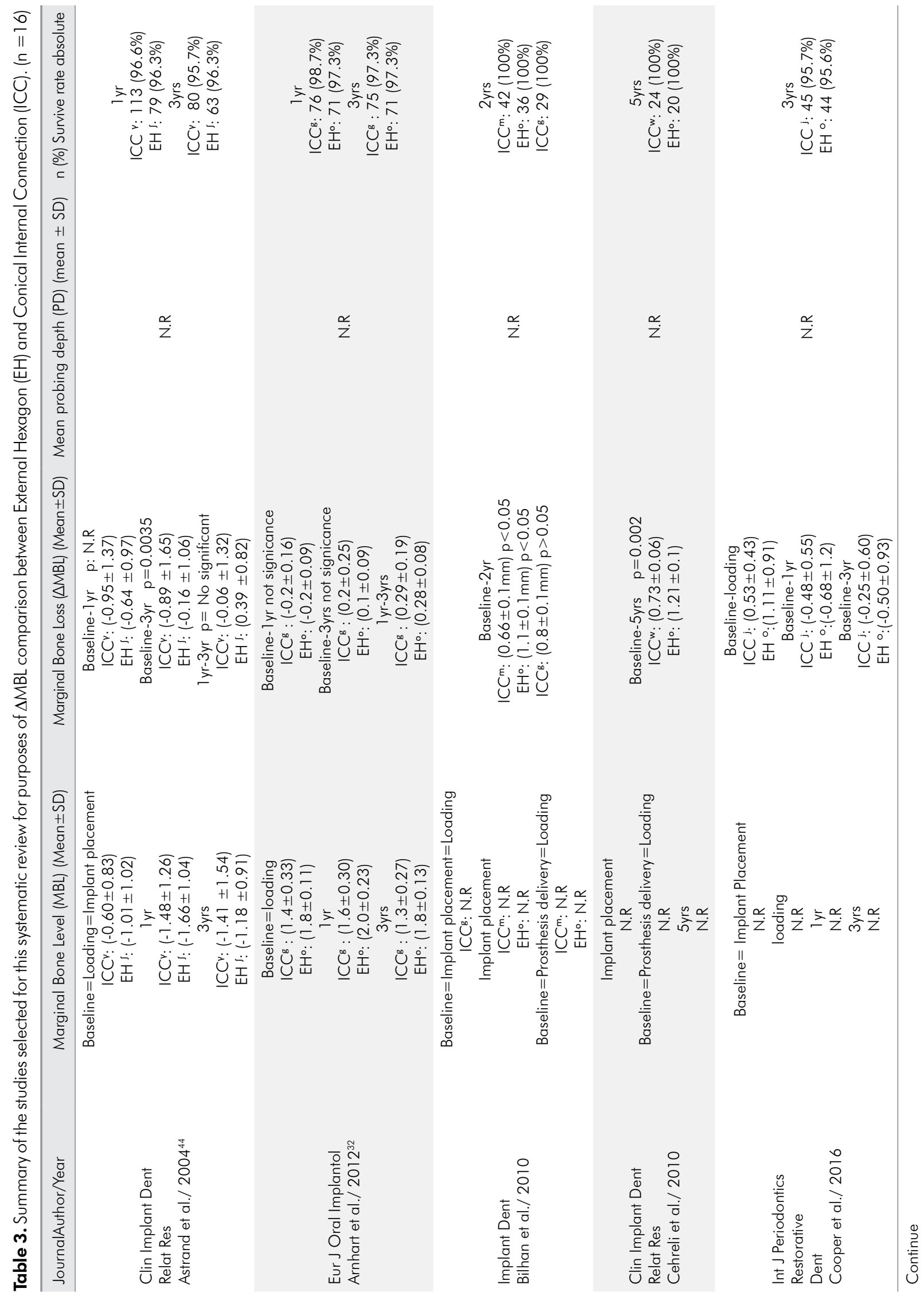




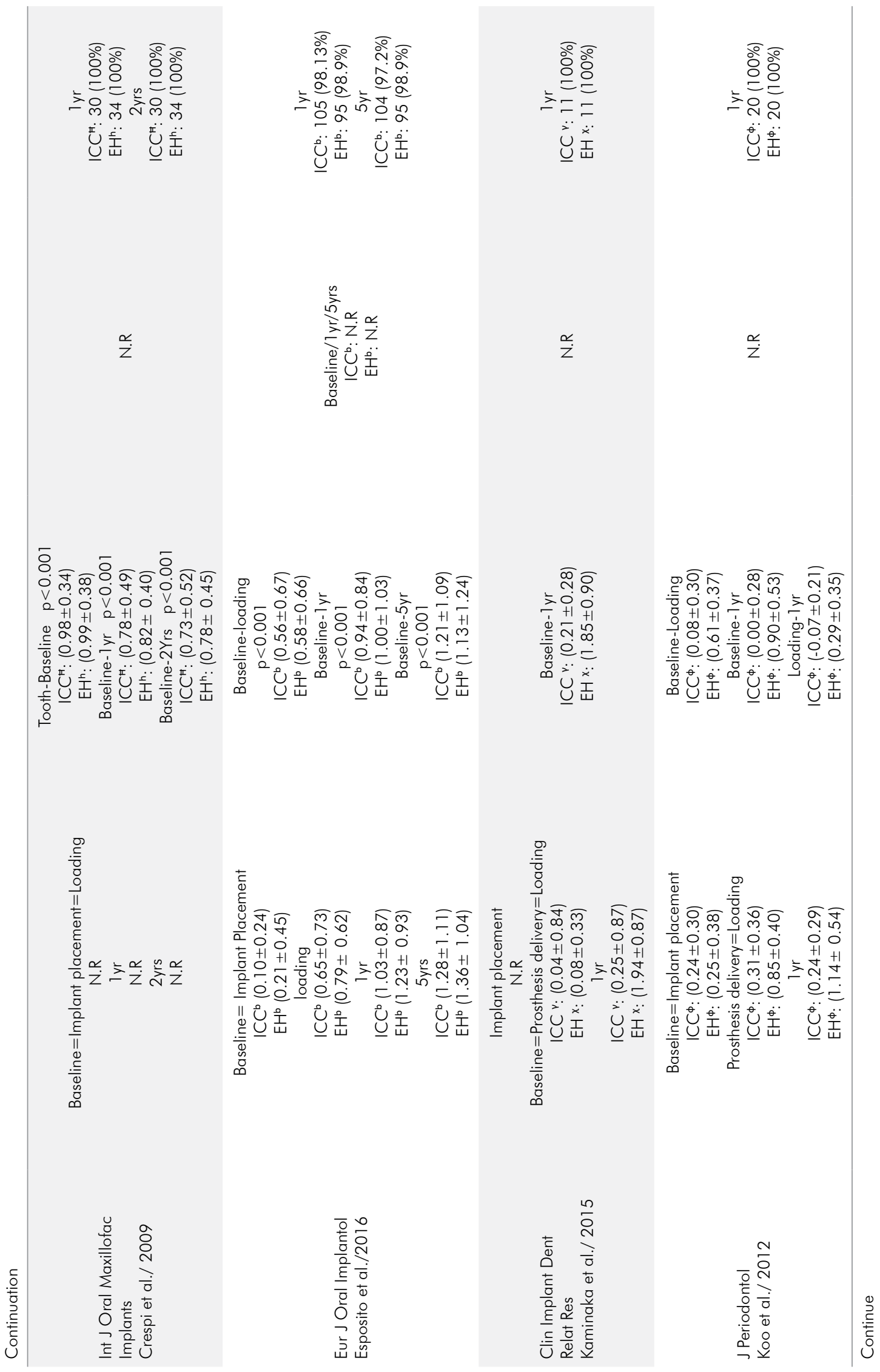




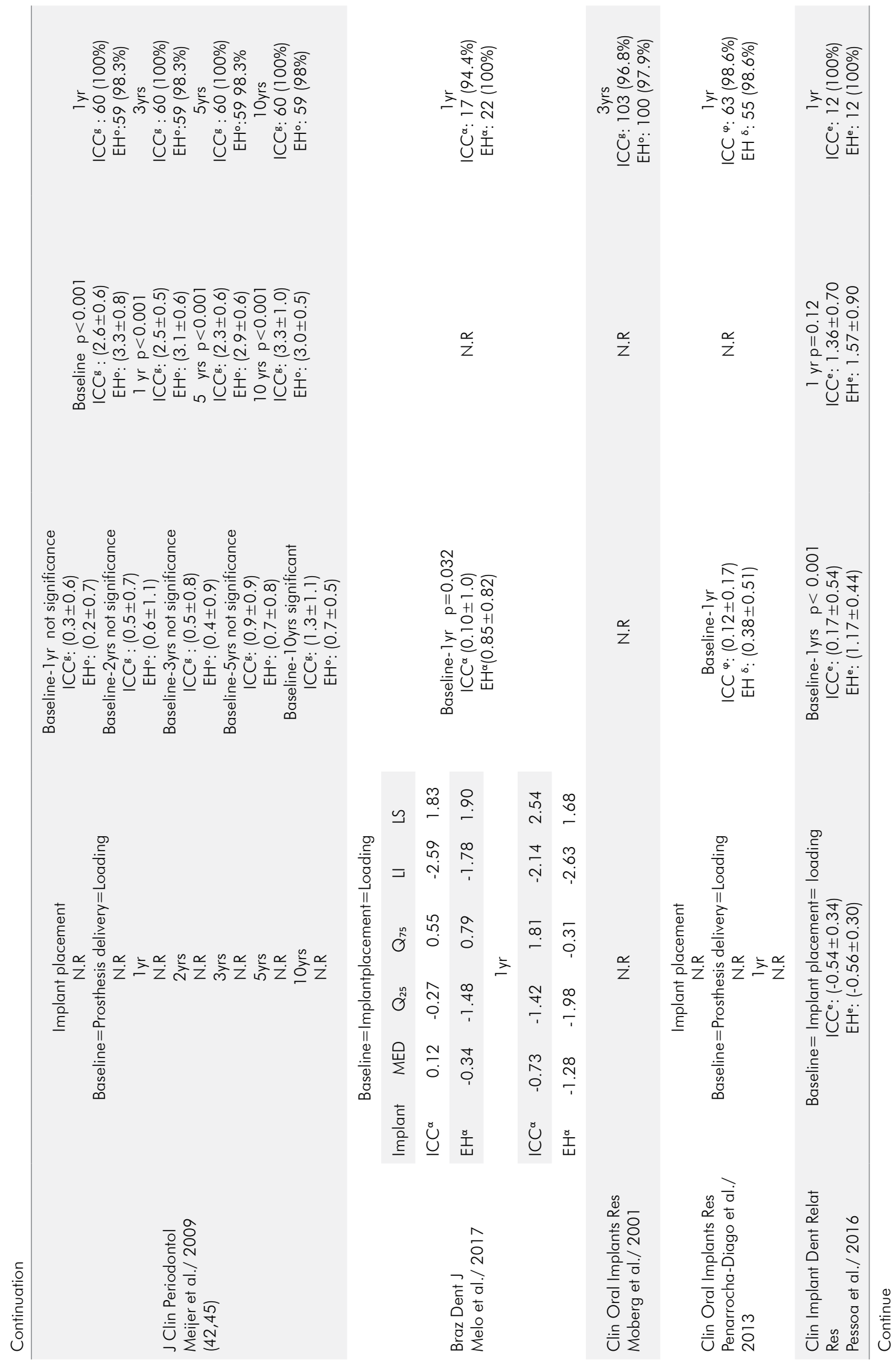




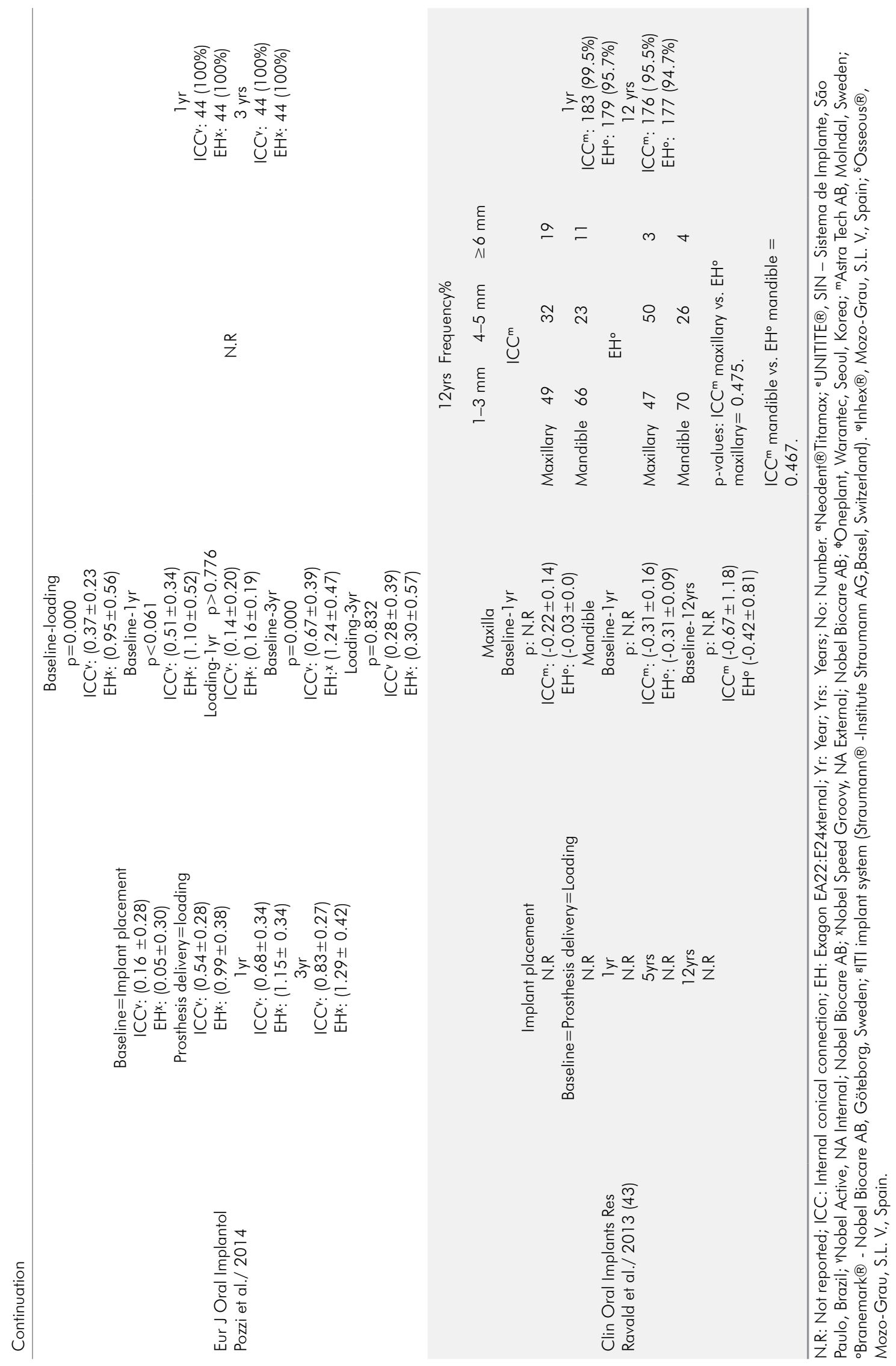




\section{Individual studies-associated bias}

The quality assessment of randomized clinical trials selected were conducted in an independent and individual manner by three trained and calibrated reviewers (ECR, CMS and TL) that used the Cochrane Collaboration RoB 2.0 tool to evaluate the risk of bias in randomized studies. ${ }^{31}$ Such tool is comprised of seven criteria including a) random sequence generation, b) allocation concealment, c) selective reporting, d) other source of bias, e) blinding (participants and personnel) and f) incomplete outcome data, where in randomization and allocation (items $a$ and $b$, respectively) were considered key-domains.

Manuscripts included in the present research were then classified as being associated with either "low" (green and positive), "high" (red and negative) or "unclear" (yellow and question mark) risk of bias according to Cochrane's Handbook for Systematic Reviews of Interventions (V 5.1.0, publicly available at http://handbook.cochrane.org). The classification described was based on allocation concealment and random sequence generation (key-domains). Studies classified as "low risk of bias" described and presented both key domains, studies classified as "high risk of bias" described but didn't present either one or both of the key domains and, studies classified as "unclear risk of bias" didn't describe and present one or both key-domains.

\section{Results}

Data of the studies classified as "low risk of bias" or "unclear risk of bias" were meta-analyzed using the Review Manager software (V. 5.3, Cochrane Collaboration, The Nordic Cochrane Center, Copenhagen, Denmark). A total of 8,851 studies were found by the research strategy described. After the removal of duplicated studies, the total number of manuscripts included was reduced to 6,382 studies. Six additional studies ${ }^{26,29,32,33,34,35}$ extracted from other data bases were added to that number to result in a total of 6,388 studies. After the dynamic reading of titles and abstracts, the total number of studies was further reduced to 641 and 29, respectively. Full-texts of manuscripts were obtained to evaluate the studies according to the inclusion and exclusion criteria of the present study. Eight studies were excluded, wherein, four studies ${ }^{36,37,38,39}$ were not comparing between EH and IC, one study was not open access ${ }^{40}$ and three other studies described patients that received bone grafts as part of their oral rehabilitation treatments. ${ }^{23,25,41}$ From the remaining 21 studies, five ${ }^{32,42,43,44,45}$ were longitudinal with distinct follow-up periods, and therefore, displayed overlap of data-sets and patient-related information. These manuscripts were referenced in tables 2 and 3 of the present study. Thus, data from only 16 studies ${ }^{26,27,28,29,33,34,35,46,47,48,49,50,51,52,53,54}$ were included for the meta-analysis portion of the study.

The results shown in Table 2 were alphabetically sorted in terms of authors' last names to facilitate the distribution and visualization of data. Parallel studies $(\mathrm{n}=13)^{26,28,33,34,35,46,48,49,50,51,52,54}$ have prevailed in the present systematic review of the literature. Only 3 studies ${ }^{27,47,53}$ were associated with a split-mouth experimental design. The total number of participants in the studies selected ranged between 12 and 206. The total number of patients considered in the present study was 841 . Only one study ${ }^{34}$ did not include the total number of patients treated with either EH or IC. The total number of dental implants placed considered in the present study was 1885 . The number of implants placed per group ranged from 12 (both $\mathrm{EH}^{53}$ and IC) up to $184 / 187$ (IC/EH, respectively)..$^{54}$

Considering the age and gender of participants, the percentage of men ranged from 21.4 to $70 \%$, and the mean age reported also varied amongst the studies selected, ranging from 48.73 to 74.4 years of age. In regards to implant placement localization (either superior or inferior arches), nine studies $28,29,33,34,35,46,48,50,54$ had implants placed in both of the arches, six studies ${ }^{26,27,49,51,5253}$ placed implants only in the mandibular bone and one study ${ }^{47}$ described implants being place only in the maxilla. Another important variable investigated was the type of prosthetic implant-supported rehabilitation. Two studies ${ }^{47,48}$ described the utilization of fixed partial prosthesis, five studies ${ }^{27,28,34,35,50}$ described fixed single-units, three studies ${ }^{52,53,54}$ described overdentures, three studies ${ }^{29,33,46}$ described implantsupported total fixed rehabilitation and finally, three 
studies ${ }^{29,33,46}$ described a combination of techniques. In regard to the functional loading of the implants placed, the studies reported immediate $(n=3)^{26,46,53}$, premature $(n=1)^{49}$ and delayed $(n=9)^{27,33,34,35,47,50,51,52,54}$. Other three studies ${ }^{28,29,48}$ described a combination of loading techniques.

In regards to follow-up periods after implant placement, the following information could be extracted: five studies ${ }^{26,33,34,50,53}$ assessed their patients one year after functional loading, one study ${ }^{48}$ assessed their patients two years and one study ${ }^{48}$ assessed their patients at one and two years after implants placement. Other two studies ${ }^{35,52}$ reported data for 3 years of follow-up and three studies ${ }^{27,46,47}$ reported data collected at 1 and 3 years after placement, two studies ${ }^{29,49}$ reported data after 5 years of placement and only one study ${ }^{51}$ reported data for $1 \frac{1 / 2}{2}$ and 10 years. Finally, only one study ${ }^{54}$ reported follow-up data from 1 and 12 years. Data regarding lost implants per groups have demonstrated that seven studies $^{28,34,48,49,50,53,54}$ have reported no losses. The remaining studies $29,33,35,46,47,51,52,54$ reported a total of 22 and 24 implants for IC and EH, respectively.

Table 3 shows the results from the radiographic assessment of $\triangle \mathrm{MBL}$ in each follow-up period. The functional loading baseline determination was also observed to very depending on the studies. Five studies ${ }^{27,29,35,50,52}$ considered the placement of implant (without functional loading), other five studies ${ }^{26,28,46,48,53}$ considered implants with immediate functional loading and six studies ${ }^{33,34,47,49,51,54}$ considered the moment of prosthesis as their baseline. In 9 studies $^{26,28,33,35,48,49,51,52,54} \Delta \mathrm{MBL}$ data was not recorded. In regards to $\triangle \mathrm{MBL}$, higher mean values were detected for $\mathrm{EH}$ at one year $(1.85 \pm 0.9 \mathrm{~mm}),{ }^{34}$ three years $(0.5 \pm 093 \mathrm{~mm})^{35}$ and five years $(1.21 \pm 0.1 \mathrm{~mm})^{49}$ of follow-up. The highest values of $\triangle \mathrm{MBL}$ observed for IC at one, three and five years of follow-up were $0.95 \pm 1.37 \mathrm{~mm}, 0.89 \pm 1.65 \mathrm{~mm}$ and $1.21 \pm 1.09 \mathrm{~mm}$, respectively.

In regards to probing depth (PD) only two manuscripts ${ }^{51,53}$ have provided sufficient data for the meta-analysis. One study ${ }^{51}$ has demonstrated that the highest PD values for $\mathrm{EH}$ and IC, within one year, were $3.1 \pm 0.6 \mathrm{~mm}$ and $2.5 \pm 0.5 \mathrm{~mm}$, respectively. Seven studies $27,28,34,48,49,50,51,52,53$ have reported $100 \%$ of implant survival rates after one-year for both types of implant-pillar connections (EH and IC). Two studies have demonstrated the lowest one-year survival rates for $\mathrm{EH}(97.7 \%)^{54}$ and IC $(94.4 \%)^{26}$ amongst all manuscripts. For 3-year survival rates, the lowest values observed were $95.6 \%{ }^{35}$ and $95.7 \%{ }^{35,46}$ for $\mathrm{EH}$ and IC, respectively. Finally, the lowest values of 5-year survival rates were found for $\mathrm{EH}(98.3 \%)^{51}$ and IC $(97.2 \%)^{29}$ implants.

\section{Assessment of bias risk}

The assessment of bias risk associated with the manuscripts selected is shown in Figure 2. The random sequence generation and allocation concealment were determined as key-domains in the present study. Ten studies $^{28,33,47,48,49,50,51,52,53,54}$ did not report the methodology used during the processes of randomization and/or allocation of implants, and therefore, were classified as "unclear risk of bias". Two studies ${ }^{26,34}$ did not perform the randomization and the allocation concealment of implants, and therefore, were classified as "high risk of bias". Finally, four studies ${ }^{27,29,35,46}$ have adequately reported the methodologies for the randomization and/or allocation of implants, and therefore, were classified as "low risk of bias".

\section{Meta-analysis}

The meta-analysis was performed using the results extracted from studies classified either as a "low" or "unclear" risk of bias, which included complete follow-up outcomes for $\triangle \mathrm{MBL}$ and survival rates (1, 3 and 5 years), and PD values (one year).

\section{Marginal bone loss ( $\triangle M B L$ )}

The first $\triangle \mathrm{MBL}$ analysis included 10 studies ${ }^{27,28,29,33,46,47,50,51,53,54}$ with one year of follow-up. The difference between median values (MD) was -0.06 with a $95 \%$ confidence interval from - 0.14 to $0.02(p=0.11)$. As denoted in Figure 3, the analyzed data set was heterogeneous $\left(\mathrm{Tau}^{2}=0.01 \mathrm{e} \mathrm{Chi}^{2}=52.64\right.$, $\mathrm{p}<0.00001 ; \mathrm{I}^{2}=83 \%$ ). The analysis of data sensitivity could not indicate which study has skewed the results. Statistical significant differences among the groups was not found, thereby demonstrating that there is no significant $\triangle \mathrm{MBL}$ differences between $\mathrm{EH}$ and IC after one year of prosthetic functional loading. 
Does the implant-abutment interface interfere on marginal bone loss? A systematic review and meta-analysis

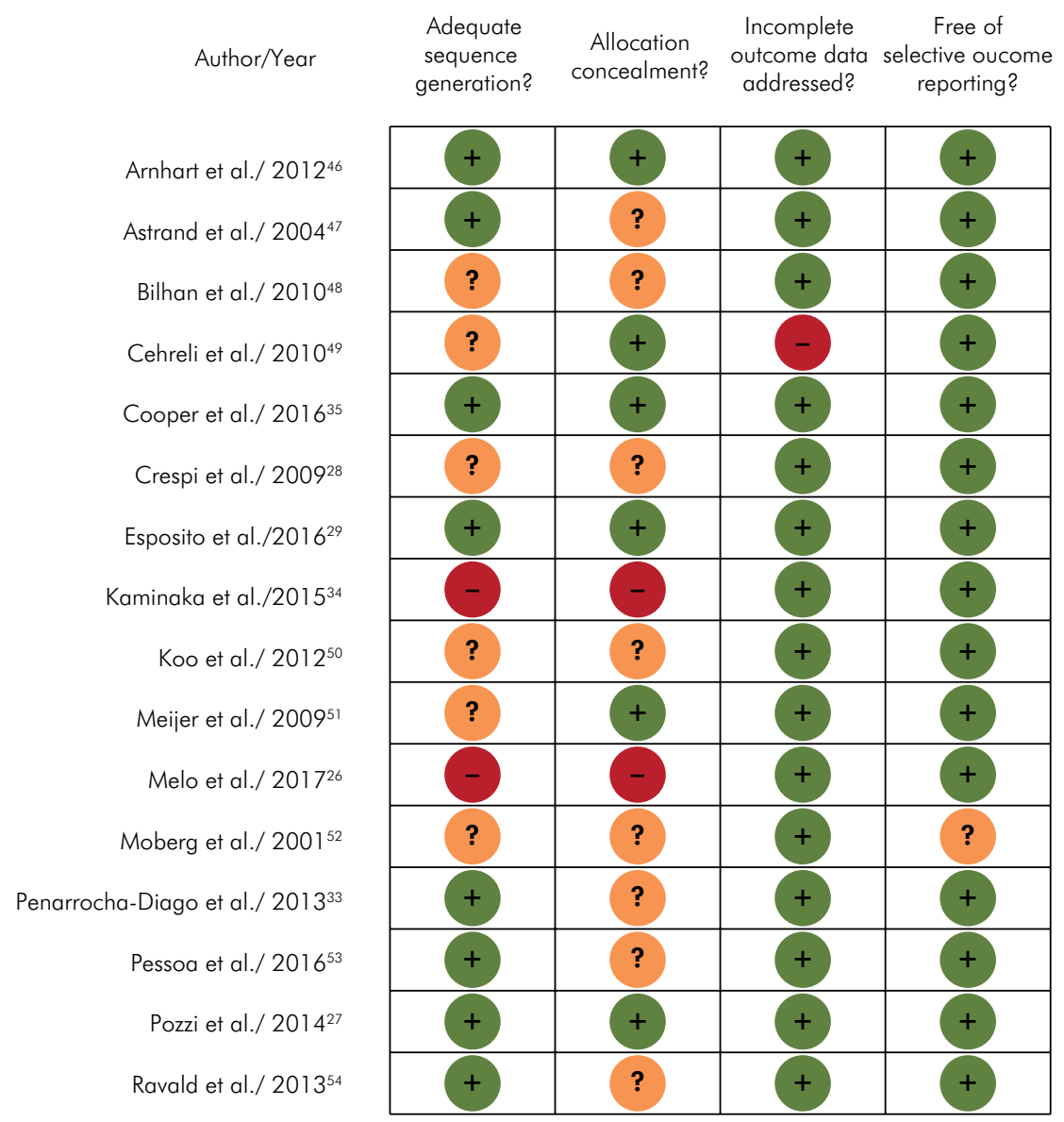

Figure 2. Summary of the risk of bias assessment according to the Cochrane Collaboration tool.

\begin{tabular}{|c|c|c|c|c|c|c|c|c|c|c|}
\hline \multirow{3}{*}{$\begin{array}{l}\text { Study or Subgroup } \\
\text { Arnhart et al } 2012\end{array}$} & \multirow{3}{*}{$\begin{array}{c}\text { Mean } \\
0.95\end{array}$} & \multicolumn{3}{|l|}{ ICC } & \multicolumn{2}{|l|}{ EH } & \multirow[b]{2}{*}{ Weight } & \multirow[b]{2}{*}{$\begin{array}{l}\text { Mean Difference } \\
\text { IV, Random, } 95 \% \mathrm{Cl}\end{array}$} & \multirow{2}{*}{\multicolumn{2}{|c|}{$\begin{array}{l}\text { Mean Difference IV, Random, } \\
95 \% \mathrm{Cl}\end{array}$}} \\
\hline & & SD & Total & Mean & SD & Total & & & & \\
\hline & & 0.37 & 113 & 0.64 & 0.97 & 79 & $7.1 \%$ & $0.31[0.09,0.53]$ & & $\longrightarrow$ \\
\hline Astrand et al 2004 & 0.2 & 0.16 & 76 & 0.2 & 0.09 & 71 & $16.9 \%$ & $0.00[-0.04,0.04]$ & & - \\
\hline Crespi et al 2009 & 0.78 & 0.49 & 30 & 0.82 & 0.4 & 34 & $7.3 \%$ & $-0.04[-0.26,0.18]$ & & \\
\hline Esposito et al 2016 & 0.94 & 0.84 & 105 & 1 & 1.03 & 95 & $5.9 \%$ & $-0.06[-0.32,0.20]$ & & \\
\hline Koo et al 2012 & 0.07 & 0.21 & 20 & 0.29 & 0.35 & 20 & $9.1 \%$ & $-0.22[-0.40,-0.04]$ & & \\
\hline Meijer et al 2009 & 0.3 & 0.6 & 60 & 0.2 & 0.7 & 59 & $6.8 \%$ & $0.10[-0.13,-0.13]$ & & \\
\hline Penarrocha et al 2013 & 0.12 & 0.17 & 55 & 0.38 & 0.51 & 63 & $11.6 \%$ & $-0.26[-0.39,-0.13]$ & & \\
\hline Pessoa et al 2016 & 0.17 & 0.54 & 12 & 1.17 & 0.44 & 12 & $3.2 \%$ & $-1.00[-1.39,-0.61]$ & 4 & \\
\hline Pozzi et al 2014 & 0.14 & 0.2 & 44 & 0.16 & 0.19 & 44 & $14.8 \%$ & $-0.02[-0.10,0.06]$ & & \\
\hline Ravald et al 2013 & 0.31 & 0.16 & 183 & 0.31 & 0.09 & 179 & $17.4 \%$ & $0.00[-0.03,0.03]$ & & \\
\hline \multicolumn{3}{|l|}{ Total $(95 \% \mathrm{Cl})$} & 698 & & & 656 & $100.0 \%$ & $-0.06[-0.14,0.02]$ & & \\
\hline \multicolumn{9}{|c|}{ Heterogeneity: $\mathrm{Tau}^{2}=0.01: \mathrm{Chi}^{2}=52.64, \mathrm{df}=9(\mathrm{P}<0.00001):\left.\right|^{2}=83 \%$} & $-0.2-0.1 \quad 0$ & 0.10 .2 \\
\hline \multicolumn{9}{|c|}{ Test for overall effect: $Z=1.58(P=0.11)$} & Favours [ICC) & Favours $[\mathrm{EH}]$ \\
\hline
\end{tabular}

Figure 3. Marginal bone loss after 1 year. 


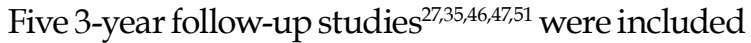
for the $\triangle \mathrm{MBL}$ analysis. According to the results obtained, the differences of MD values was 0.08 with $95 \%$ confidence interval from -0.10 to $0.27(\mathrm{p}=0.38$ ). As denoted in Figure 4, the analyzed data set was heterogeneous $\left(\mathrm{Tau}^{2}=0.03\right.$ e $^{-C^{2}}=12.80, \mathrm{p}=0.01$; $\left.\mathrm{I}^{2}=69 \%\right)$. The analysis of data sensitivity was not able to discriminate which study skewed the results and no statistical differences were observed between $\mathrm{EH}$ and IC for $\triangle \mathrm{MBL}$ at 3 years of follow-up. Insert Figure 4

The analysis of $\triangle \mathrm{MBL}$, three studies ${ }^{29,49,51}$ of 5 years of follow-up were included in the present study, wherein the differences among MD values was -0.08 with confidence interval of $95 \%$ from -0.59 to $0.42(p=0.74)$. A denoted in Figure 5, the analyzed data was found to be heterogeneous $\left(\mathrm{Tau}^{2}=0.18 \mathrm{e}\right.$ $\left.\mathrm{Chi}^{2}=28.91 \mathrm{p}<0.00001 ; \mathrm{I}^{2}=93 \%\right)$. These results lead to a sensitivity analysis and the removal of 1 study. ${ }^{49}$
After that procedure, the remaining studies became homogenous, but no significant statistical differences were observed.

\section{Implant survival rates}

The assessment of implant survival rates included 10 studies ${ }^{27,28,29,33,46,47,50,51,53,54}$ with one year of follow-up. The relative risk (RR) was 1.01 with confidence interval of $95 \%$ varying from 1.00 to $1.03(p=0.18)$. As denoted in Figure 6, the data set analyzed did not result in heterogeneity $\left(\mathrm{Tau}^{2}=0.00\right.$ e $\mathrm{Chi}^{2}=4.93, \mathrm{p}=0.84 ; \mathrm{I}^{2}=0 \%$ ). Statistical significant differences were not found between implants pertaining to both EH and IC. An additional survival rate analysis included 5 studies ${ }^{27,35,46,47,51}$ with 3 years of follow-up. The RR was 0.99 with confidence interval of $95 \%$ varying from 0.96 and $1.03(p=0.63)$. As denoted in Figure 7, the data set was found to be heterogeneous $\left(\mathrm{Tau}^{2}=0.00 \mathrm{e} \mathrm{Chi}^{2}=\right.$

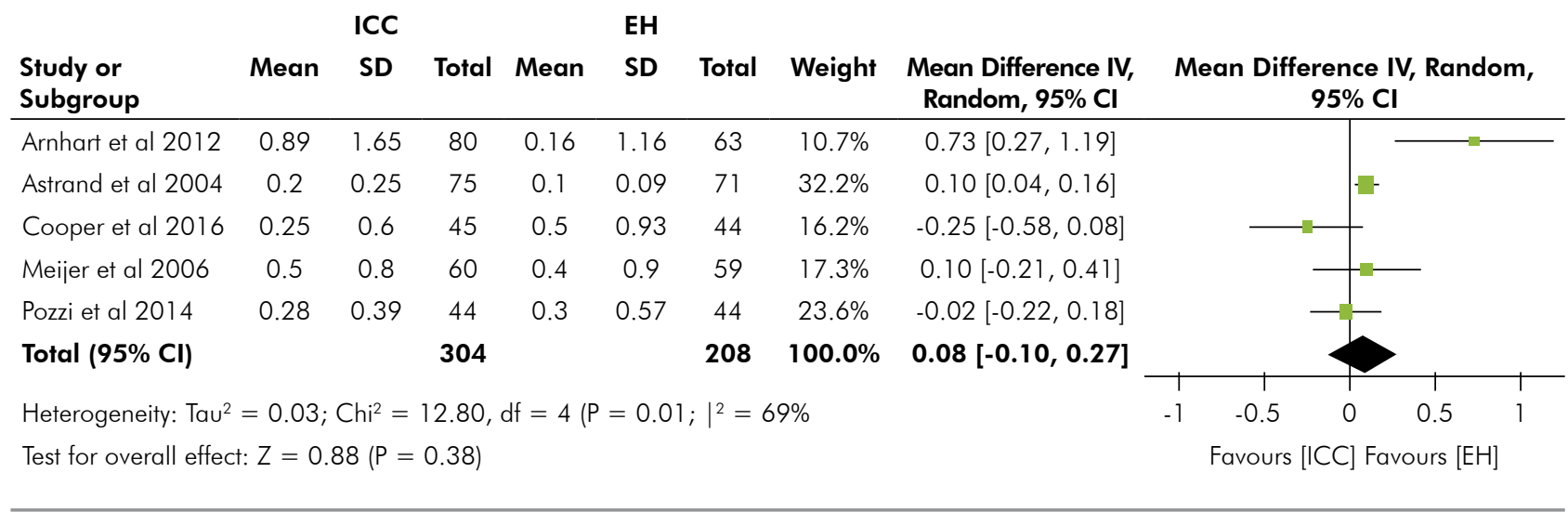

Figure 4. Marginal bone loss after 3 years.

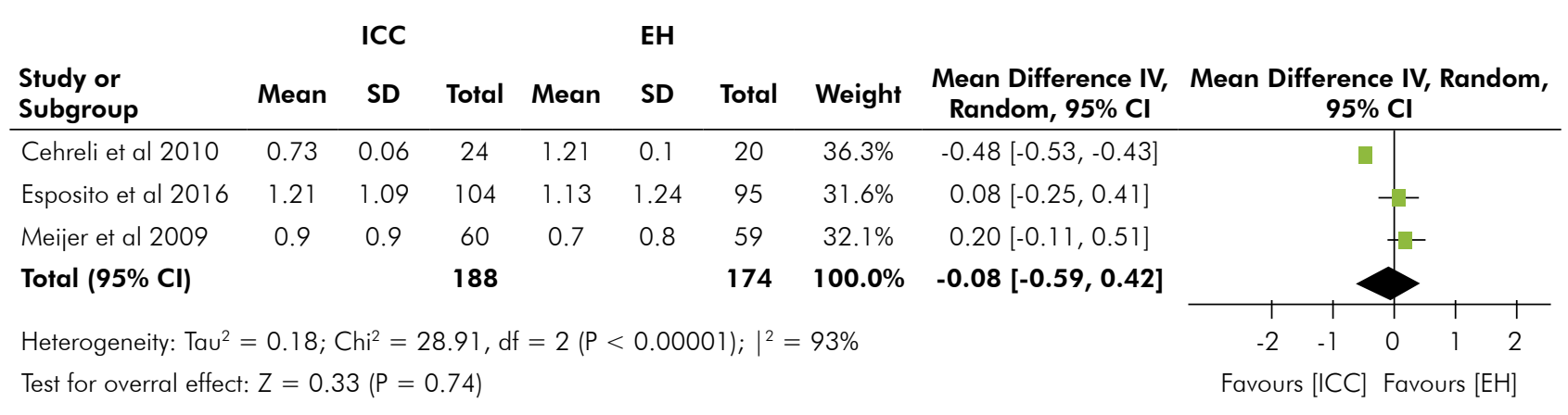

Figure 5. Marginal bone loss after 5 years. 
Does the implant-abutment interface interfere on marginal bone loss? A systematic review and meta-analysis

$\left.8.25, \mathrm{p}=0.08 ; \mathrm{I}^{2}=52 \%\right)$. The sensitivity analysis led to the removal of one manuscript, which resulted in the attainment of zero heterogeneity of data. No statistical significant differences were observed for implants of EH or IC in 3-year follow-up studies.

Finally, three studies ${ }^{29,49,51}$ with 5 years of follow-up were included in the analysis of implant survival rates. The RR was 0.99 with confidence interval of $95 \%$ varying from 0.98 to $1.02(\mathrm{p}=0.62)$. The data set was not heterogeneous $\left(\mathrm{Tau}^{2}=0.00 \mathrm{e} \mathrm{Chi}^{2}=0.19\right.$, $\left.\mathrm{p}=0.91 ; \mathrm{I}^{2}=0 \%\right)$, as shown in Figure 8 and no statistical differences were observed between the survival rates of implants of EH or IC.

\section{Probing Depth (PD)}

The analysis of PD included 2 studies ${ }^{51,53}$ with 1 year of follow-up. The difference of median values was -0.53 with confidence interval of $95 \%$ from -0.82 to 0.24 ( $p=0.0004)$. The data was not heterogeneous $\left(\mathrm{Tau}^{2}=0.02 \mathrm{e} \mathrm{Chi}^{2}=1.28 \mathrm{p}=0.26 ; \mathrm{I}^{2}=22 \%\right)$, as can be observed in Figure 9. Significant statistical differences were observed between $\mathrm{EH}$ and IC, wherein better

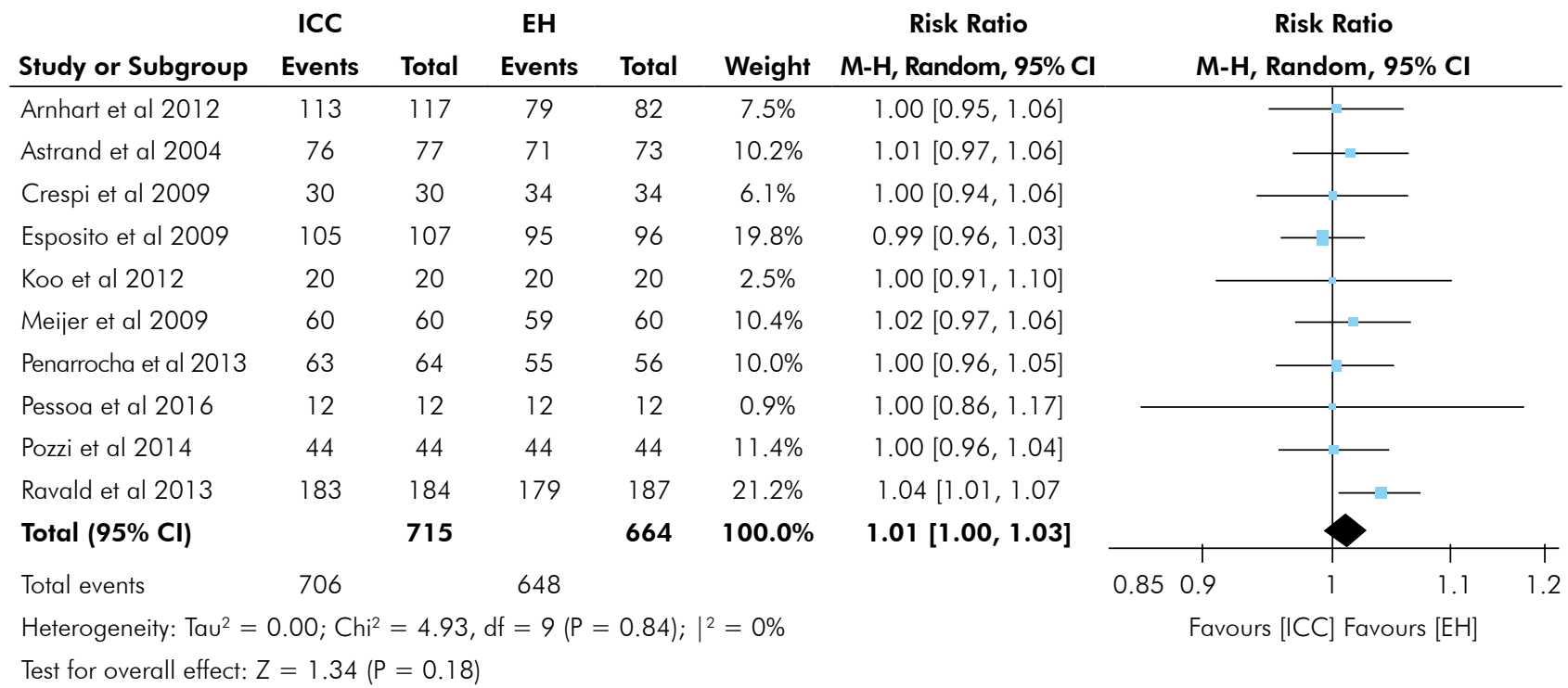

Figure 6. Implant survival rates after 1 year.

ICC EH

\begin{tabular}{lcccccc} 
Study or Subgroup & Events & Total & Events & Total & Weight & M-H, Random, 95\% C \\
\hline Arnhart et al 2012 & 75 & 76 & 71 & 71 & $28.6 \%$ & $0.99[0.95,1.02]$ \\
Astrand et al 2004 & 80 & 113 & 63 & 79 & $3.9 \%$ & $0.89[0.75,1.04]$ \\
Cooper et al 2016 & 45 & 47 & 44 & 46 & $11.3 \%$ & $1.00[0.92,1.09]$ \\
Meijer et al 2009 & 60 & 60 & 59 & 59 & $31.0 \%$ & $1.00[0.97,1.03]$ \\
Pozzi et al 2014 & 44 & 44 & 44 & 44 & $25.1 \%$ & $1.00[0.96,1.04]$ \\
Total (95\% Cl) & & $\mathbf{3 4 0}$ & & $\mathbf{2 9 9}$ & $\mathbf{1 0 0 . 0 \%}$ & $\mathbf{0 . 9 9}[\mathbf{0 . 9 6}, \mathbf{1 . 0 3}]$ \\
Total events & 304 & & 281 & & &
\end{tabular}

Heterogeneity: $\mathrm{Tau}^{2}=0.00 ; \mathrm{Chi}^{2}=8.25, \mathrm{df}=4(\mathrm{P}=0.08) ; \mid 2=52 \%$

Test for overall effect: $Z=0.48(P=0.63)$
Risk Ratio Risk Ratio M-H, Random, 95\% Cl

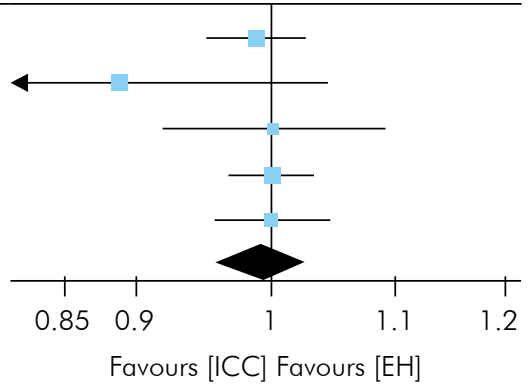

Figure 7. Implant survival rates after 3 years. 
ICC

EH

Risk Ratio

Risk Ratio

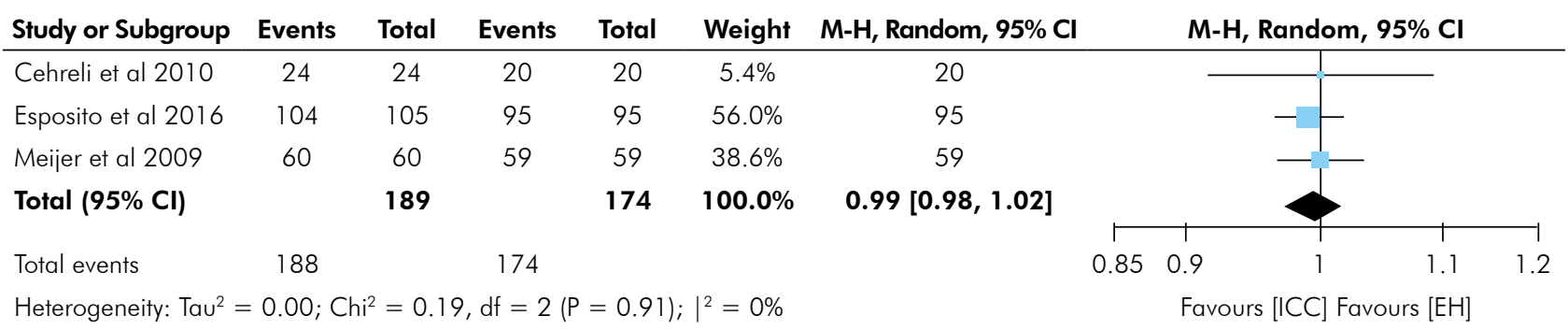

Test for overall effect: $Z=0.49(P=0.62)$

Figure 8. Implant survival rates after 5 years.

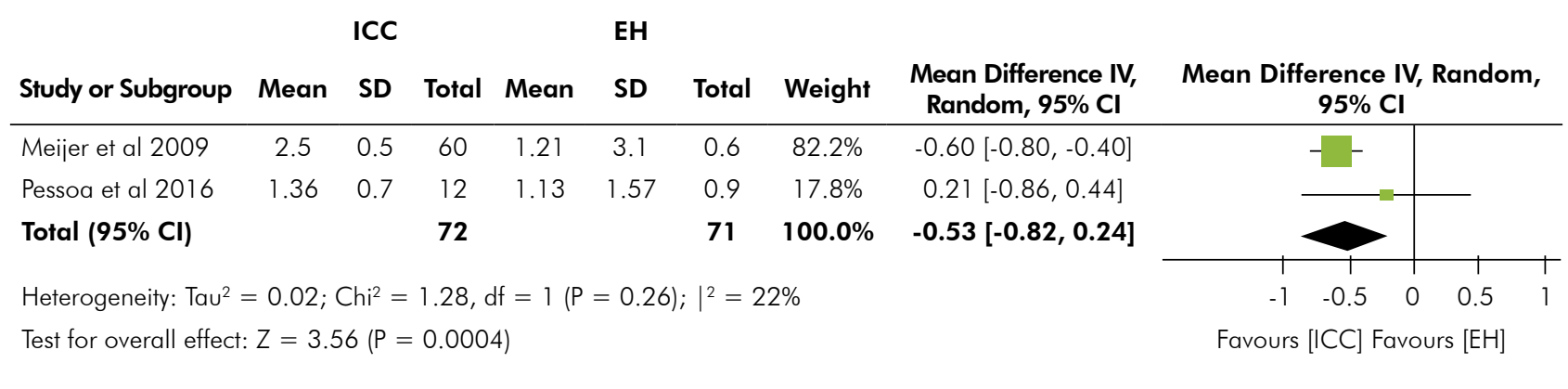

Figure 9. Probing depth after 1 year.

PD values were observed for implants pertaining to the IC group.

\section{Discussion}

The present systematic review of the literature had the primary objective to identify which implantpillar connection provides with the lowest $\triangle \mathrm{MBL}$ values after the installation of the prosthesis and the beginning of implants functional loading.

The question regarding which type of implantpillar connection is better regarding peri-implant marginal bone loss is justifiable because $35 \%$ of the worldwide population is edentulous, and dental implants are considered the only type of oral rehabilitation strategy capable of restoring the masticatory function, deglutition and speech, and is capable of maintaining bone level while displaying superior levels of prosthesis stability and remarkable social and psychological well-being. ${ }^{1,55}$ Initially, implants with EH connections were considered the first option amongst clinicians. However, with the evolution of materials and implant designs, IC became the most common type of implants used due to their superior biological and biomechanical properties. ${ }^{16}$ It has been previously shown that the superior biomechanical results reported for IC implants are associated with more adequate distribution of masticatory forces in the longitudinal-axis of the pillar-implant-bone complex which results in enhanced biological properties due to a better separation between the micro-sized gap and bone that respects the requirements for a healthy biological space. ${ }^{56}$

The results of the present systematic review at one-year $\triangle \mathrm{MBL}$ have demonstrated that no significant statistical differences were observed among the groups. However, the results from the meta-analysis has detected high heterogeneity levels among the studies investigated. Such behavior could not be explained by the sensitivity analysis probably because of the different types of prosthetic rehabilitation techniques, different placement locations and functional loading baselines..$^{29}$ Other factors that might have contributed for the observation of such results are related to 
implant design, surface treatment and presence or absence of short platforms. ${ }^{33,46,50}$

The heterogeneity observed during the metaanalysis of 3-year follow-up studies in regard to $\triangle \mathrm{MBL}$ values, can be partially explained by the diversity of functional loading protocols, types of prosthetic rehabilitations, implant design and surface treatments. Even with such heterogeneity of results, no statistical significant differences were observed for $\triangle \mathrm{MBL}$ between $\mathrm{EH}$ and IC implants. The findings of the present study have been corroborated by previous studies published by Ganeles et al. ${ }^{57}$ and Esposito et al. ${ }^{58}$ The $\Delta \mathrm{MBL}$ values after 5 years of follow-up reported in the study published by Cehreli et al..$^{49}$ have rendered the meta-analysis data of the present study as heterogeneous. This trend could have happened because of the premature functional loading of overdenture prosthetic restorations. When these results were removed from the present metaanalysis, the results became homogenous.

High levels of heterogeneity were also observed for studies with 3 years of follow-up. The sensitivity analysis indicated that data extracted from the manuscript published by Astrand et al. ${ }^{47}$ was the sole responsible for such a trend. These results could be explained by the location restriction imposed by the assessment of that particular manuscript, that only investigated dental implants placed in the maxillary bone (less dense and more trabecular in nature). It well-known that lack of bone density can adversely impact the obtained results because of the rise of tensile forces at peri-implant locations that may lead to significant $\triangle$ MBL. ${ }^{59}$

For the 1 and 5 -year survival rates (homogenous data sets for both time-periods), no statistical differences could be detected between EH and IC. The assessment of PD values indicated that IC implants were associated with better values (statistically significant differences). However, the results were only associated with a mild heterogeneity that might be explained by the small number of studies analyzed $(\mathrm{n}=2)^{51,53}$ Two systematic review studies ${ }^{60,61}$ recently published have reported findings for $\mathrm{EH}$ and IC that do not corroborate the results of the present study. Nonetheless, the present study had a more robust and broader search strategy and covered studies without any language restrictions for follow-up assessments of 1, 3 and 5 years after the prosthetic loading of implants. The manuscripts investigated in the present systematic review study were used to compare the results between implants of EH or IC connections, where studies that utilized bone grafts as part of their treatment plans were excluded from the present analysis.

Marginal bone loss can be influenced by other factors than implant-pillar connection, including other technical differences such as implant design, ${ }^{62}$ reduced platform, ${ }^{41,63,64}$ micron-sized gap position ${ }^{18,65}$ and surface treatment. ${ }^{66,67,68,69}$ These factors combined, may have directly influenced the $\triangle \mathrm{MBL}^{16}$ and the heterogeneity of the results of the present systematic review of the literature. According to the retrospective study recently published by Galindo-Moreno et al., ${ }^{62}$ the microstructure or the design of the implant adversely impacted the $\triangle \mathrm{MBL}$ in peri-implant areas, possibly due to the generation of unbalanced tensile forces in the long-axis of the implant fixture. Some clinical studies included in the present systematic review have compared implants of distinct connections, similar microstructures and identical surface treatments, ${ }^{29,46,50,53}$ which might have decreased the heterogeneity associated with the studies investigated. Nonetheless, the majority of the studies included described the use of implants of different designs and surface treatments. These types of surface treatment may positively influence the osseointegration of dental implants, may upregulate the adhesion and proliferation of osteoblastic cells and may even increase the surface area available for attachment. ${ }^{66,67,68,69}$

Another important point that must be considered is the presence of reduced implant platforms. These might have generated some of the differences detected among the manuscripts investigated in the present study. Some of these studies have correlated low $\triangle \mathrm{MBL}$ values with the presence of reduced implant platforms. ${ }^{41,63,64,70,71}$ From all the studies investigated, only 3 studies ${ }^{33,46,50}$ have compared $\mathrm{EH}$ and IC implants with reduced platforms, while other studies ${ }^{27,28,49}$ have IC implants with or without reduced platforms, thus increasing the difficulty 
levels associated with interpretation of results. Bacterial penetration and biofilm formation at the micro-sized gap is another relevant point that may adversely influence the results between different types of implant connections. The position of the micron-sized gap at the implant-pillar connection has been recognized to generate $\triangle \mathrm{MBL}$ and intense bone remodeling, through a saucerization process, due to its close proximity to the cortical bone. ${ }^{18,65,72,73}$

The types of prosthetic rehabilitation strategies described (fixed partial or total, single unit and overdenture) in the clinical trials selected is another relevant topic that must be underscored, because each type of technique results in unique masticatory dynamics and particular hygiene procedures. ${ }^{74,75}$ Moreover, a large variability of functional loading protocols were described in the manuscripts selected. These factors combined, might have impacted the ability of the authors to significant statistical differences among the types of implants analyzed and functional loading baselines (immediate, premature or delayed). ${ }^{7,58}$

The experimental methodology utilized by the majority of the studies selected was based on the assessment of periapical radiographies. It is well-known that in order to correctly perform these types of measurements, it is necessary to calibrate and standardize the evaluators prior to the execution of the study. ${ }^{21,22}$ Significant limitations of radiographic assessments are associated with the flattening of 3-dimmensional structures into a 2-dimmensional plane. Three-dimensional computer tomography (CT-scan) ${ }^{21}$ has been shown to provide with high-resolution and high-quality digital images that allow for the precise assessment of marginal bone levels at all peri-implant areas. ${ }^{23}$ Therefore CT-scans are currently considered as the preferred type of digital image assessment for dental implants.

Despite these promising characteristics, several studies have demonstrated that CT-scans and intraoral radiographies are associated with comparable levels of precision during the determination of mesial and distal bone heights. The lack of standardization in regards to the type of $\triangle \mathrm{MBL}$ image assessment (either radiographic or tomographic) is considered one the limitations detected by the present systematic review, once distinct types of techniques were utilized including the parallel technique $(n=7), 29,33,35,46,48,53,54$ custom parallel technique $(n=6),{ }^{26,27,28,47,50,51}$ panoramic X-ray $(n=2)^{48,49}$ and only one study ${ }^{34}$ used tomographic assessment. These findings further demonstrate the lack of standardization observed in the literature regarding the assessment of $\triangle \mathrm{MBL}$ in peri-implant areas. These results can be partically used to explain the high heterogeneity levels observed among the groups investigated.

Finally, in its vast majority, the investigated studies did not report their findings according to the CONSORT statement. Only three studies ${ }^{27,29,46}$ have followed this declaration in their reports, which suggest the needed for randomized clinical trials that are better designed and conducted.

\section{Conclusions}

This present systematic review demonstrated that there are no significant differences between IC and EH implants for both $\triangle \mathrm{MBL}$ and SR at 1, 3 e 5 years after functional loading, although better PD values were observed for implants pertaining to the IC connections. Considering the high heterogeneity, more well-delineated, randomized clinical trials should be conducted.

\section{References}

1. Smeets R, Stadlinger B, Schwarz F, Beck-Broichsitter B, Jung O, Precht C et al. Impact of dental implant surface modifications on osseointegration. Biomed Res Int. 2016;2016:ID6285620. https://doi.org/10.1155/2016/6285620

2. Buser D, Janner SF, Wittneben JG, Brägger U, Ramseier CA, Salvi GE. 10-year survival and success rates of 511 titanium implants with a sandblasted and acid-etched surface: a retrospective study in 303 partially edentulous patients. Clin Implant Dent Relat Res. 2012 Dec;14(6):839-51. https://doi.org/10.1111/j.1708-8208.2012.00456.x 
Does the implant-abutment interface interfere on marginal bone loss? A systematic review and meta-analysis

3. Esposito M, Ardebili Y, Worthington HV. Interventions for replacing missing teeth: different types of dental implants. Cochrane Database Syst Rev. 2014 Jul; 22(7):CD003815. https://doi.org/10.1002/14651858.CD003815.pub4

4. Esposito M, Hirsch JM, Lekholm U, Thomsen P. Biological factors contributing to failures of osseointegrated oral implants. (II). Etiopathogenesis. Eur J Oral Sci. 1998 Jun;106(3):721-64.https://doi.org/10.1046/i.0909-8836..t01-6-.x

5. Block MS. Dental Implants: The Last 100 Years. J Oral Maxillofac Surg. 2018 Jan;76(1):11-26. https://doi.org/10.1016/j.joms.2017.08.045

6. Misch CE, Perel ML, Wang HL, Sammartino G, Galindo-Moreno P, Trisi P, et al. Implant success, survival, and failure: The International Congress of Oral Implantologists (ICOI) Pisa Consensus Conference. Implant Dent. 2008 Mar;17(1):5-15. https://doi.org/10.1097/ID.0b013e3181676059

7. Albrektsson T, Zarb G, Worthington P, Eriksson AR. The long-term efficacy of currently used dental implants: a review and proposed criteria of success. Int J Oral Maxillofac Implants. 1986;1(1):11-25.

8. Cardaropoli G, Lekholm U, Wennström JL. Tissue alterations at implant-supported single-tooth replacements: a 1-year prospective clinical study. Clin Oral Implants Res. 2006 Apr;17(2):165-71. https://doi.org/10.1111/i.1600-0501.2005.01210.x

9. Albrektsson T, Dahlin C, Jemt T, Sennerby L, Turri A, Wennerberg A. Is marginal bone loss around oral implants the result of a provoked foreign body reaction? Clin Implant Dent Relat Res. 2014 Apr;16(2):155-65. https://doi.org/10.1111/cid.12142

10. Oh TJ, Yoon J, Misch CE, Wang HL. The causes of early implant bone loss: myth or science? J Periodontol. 2002 Mar;73(3):322-33. https://doi.org/10.1902/jop.2002.73.3.322

11. Tatarakis N, Bashutski J, Wang HL, Oh TJ. Early implant bone loss: preventable or inevitable? Implant Dent. 2012 Oct;21 (5):379-86. https://doi.org/10.1097/ID.0b013e3182665d0c

12. Santiago Junior JF, Verri FR, Almeida DA, de Souza Batista VE, Lemos CA, Pellizzer EP. Finite element analysis on influence of implant surface treatments, connection and bone types. Mater Sci Eng C. 2016 Jun;63:292-300. https://doi.org/10.1016/j.msec.2016.02.061

13. Binon PP. Implants and components: entering the new millennium. Int J Oral Maxillofac Implants. 2000 Jan-Feb;15(1):76-94.

14. Barbosa GS, Silva-Neto JP, Simamoto-Júnior PC, Neves FD, Mattos MG, Ribeiro RF. Evaluation of screw loosening on new abutment screws and after successive tightening. Braz Dent J. 2011;22(1):51-5. https://doi.org/10.1590/S0103-64402011000100009

15. Pellizzer EP, Lemos CA, Almeida DA, Batista VES, Santiago Júnior JF, Verri FR. Biomechanical analysis of different implant-abutments interfaces in different bone types: an in silico analysis. Mater Sci Eng C. 2018 Sep;90:645-50. https://doi.org/10.1016/i.msec.2018.05.012

16. Schmitt CM, Nogueira-Filho G, Tenenbaum HC, Lai JY, Brito C, Döring H, et al. Performance of conical abutment (Morse Taper) connection implants: a systematic review. J Biomed Mater Res A. 2014 Feb;102(2):552-74. https://doi.org/10.1002/jbm.a.34709

17. Bozkaya D, Müftü S. Mechanics of the taper integrated screwed-in (TIS) abutments used in dental implants. J Biomech. 2005 Jan;38(1):87-97. https://doi.org/10.1016/i.jbiomech.2004.03.006

18. Hermann JS, Schoolfield JD, Schenk RK, Buser D, Cochran DL. Influence of the size of the microgap on crestal bone changes around titanium implants. A histometric evaluation of unloaded non-submerged implants in the canine mandible. J Periodontol. 2001 Oct;72(10):1372-83. https://doi.org/10.1902/jop.2001.72.10.1372

19. Bozkaya D, Müftü S. Mechanics of the tapered interference fit in dental implants. J Biomech. 2003 Nov;36(11):1649-58. https://doi.org/10.1016/S0021-9290(03)00177-5

20. Koutouzis T, Wallet S, Calderon N, Lundgren T. Bacterial colonization of the implant-abutment interface using an in vitro dynamic loading model. J Periodontol. 2011 Apr;82(4):613-8. https://doi.org/10.1902/jop.2010.100415

21. Sakka S, Al-ani Z, Kasioumis T, Worthington H, Coulthard P. Inter-examiner and intra-examiner reliability of the measurement of marginal bone loss around oral implants. Implant Dent. 2005 Dec;14(4):386-8. https://doi.org/10.1097/01.id.0000188464.76640.c7

22. Kavadella A, Karayiannis A, Nicopoulou-Karayianni K. Detectability of experimental peri-implant cancellous bone lesions using conventional and direct digital radiography. Aust Dent J. 2006 Jun;51(2):180-6. https://doi.org/10.1111/j.1834-7819.2006.tb00424.x

23. Jaju PP, Jaju SP. Clinical utility of dental cone-beam computed tomography: current perspectives. Clin Cosmet Investig Dent. 2014 Apr;6:29-43. https://doi.org/10.2147/CCIDE.S41621

24. Thoma DS, Sanz Martin I, Benic GI, Roos M, Hämmerle CH. Prospective randomized controlled clinical study comparing two dental implant systems: demographic and radiographic results at one year of loading. Clin Oral Implants Res. 2014 Feb;25(2):142-9. https://doi.org/10.1111/clr.12120

25. Sanz Martin I, Benic Gl, Hämmerle CH, Thoma DS. Prospective randomized controlled clinical study comparing two dental implant types: volumetric soft tissue changes at 1 year of loading. Clin Oral Implants Res. 2016 Apr;27(4):406-11. https://doi.org/10.1111/clr.12579

26. Melo LA, Souza MB, Barbosa GA, Carreiro AD. Peri-implant bone loss of external hexagon and morse taper in patients wearing immediately loaded overdentures. Braz Dent J. 2017 Nov-Dec;28(6):694-8. https://doi.org/10.1590/0103-6440201701577

27. Pozzi A, Tallarico M, Moy PK. Three-year post-loading results of a randomised, controlled, split-mouth trial comparing implants with different prosthetic interfaces and design in partially posterior edentulous mandibles. Eur J Oral Implantol. 2014;7(1):47-61. 
Rosa EC, Deliberador TM, Nascimento TCL, Kintopp CCA, Orsi JSR, Wambier LM, et al.

28. Crespi R, Capparè P, Gherlone E. Radiographic evaluation of marginal bone levels around platform-switched and non-platform-switched implants used in an immediate loading protocol. Int J Oral Maxillofac Implants. 2009 Sep-Oct;24(5):920-6. PMID:19865633

29. Esposito M, Maghaireh H, Pistilli R, Grusovin MG, Lee ST, Trullenque-Eriksson A, et al. Dental implants with internal versus external connections: 5 -year post-loading results from a pragmatic multicenter randomised controlled trial. Eur J Oral Implantol. 2016;9(2 Suppl 1):129-41.

30. Moher D, Shamseer L, Clarke M, Ghersi D, Liberati A, Petticrew M, et al. Preferred reporting items for systematic review and metaanalysis protocols (PRISMA-P) 2015 statement. Syst Rev. 2015 Jan;4(1):1-9. https://doi.org/10.1186/2046-4053-4-1

31. Jørgensen L, Paludan-Müller AS, Laursen DR, Savović J, Boutron I, Sterne JA, et al. Evaluation of the Cochrane tool for assessing risk of bias in randomized clinical trials: overview of published comments and analysis of user practice in Cochrane and non-Cochrane reviews. Syst Rev. 2016 May; 5(5):80. https://doi.org/10.1186/s13643-016-0259-8

32. Kielbassa AM, Martinez-de Fuentes R, Goldstein M, Arnhart C, Barlattani A, Jackowski J, et al. Randomized controlled trial comparing a variable-thread novel tapered and a standard tapered implant: interim one-year results. J Prosthet Dent. 2009 May;101(5):293-305. https://doi.org/10.1016/S0022-3913(09)60060-3

33. Peñarrocha-Diago MA, Flichy-Fernández AJ, Alonso-González R, Peñarrocha-Oltra D, Balaguer-Martínez J, Peñarrocha-Diago M. Influence of implant neck design and implant-abutment connection type on peri-implant health. Radiological study. Clin Oral Implants Res. 2013 Nov;24(11):1192-200. https://doi.org/10.1111/j.1600-0501.2012.02562.x

34. Kaminaka A, Nakano T, Ono S, Kato T, Yatani H. Cone-beam computed tomography evaluation of horizontal and vertical dimensional changes in buccal peri-implant alveolar bone and soft tissue: a 1-year prospective clinical study. Clin Implant Dent Relat Res. 2015 Oct;17(17 Suppl 2):e576-85. https://doi.org/10.1111/cid.12286

35. Cooper LF, Tarnow D, Froum S, Moriarty J, De Kok IJ. Comparison of marginal bone changes with internal conus and external hexagon design implant systems: a prospective randomized study. Int J Periodontics Restorative Dent. 2016 Sep-Oct;36(5):631-42. https://doi.org/10.11607/prd.2433

36. Jung YC, Han CH, Lee KW. A 1 -year radiographic evaluation of marginal bone around dental implants. Int J Oral Maxillofac Implants. 1996 Nov-Dec;11(6):811-8.

37. Davarpanah M, Martinez H, Tecucianu JF, Alcoforado G, Etienne D, Celletti R. The self-tapping and ICE 3i implants: a prospective 3-year multicenter evaluation. Int J Oral Maxillofac Implants. 2001 Jan-Feb; 16(1):52-60.

38. Davarpanah M, Martinez H, Etienne D, Zabalegui I, Mattout $P$, Chiche F, et al. A prospective multicenter evaluation of 1,583 $3 \mathrm{i}$ implants: 1- to 5-year data. Int J Oral Maxillofac Implants. 2002 Nov-Dec;17(6):820-8.

39. Hsu YT, Chan HL, Rudek I, Bashutski J, Oh WS, Wang HL, et al. Comparison of Clinical and radiographic outcomes of platform-switched implants with a rough collar and platform-matched implants with a smooth collar: a 1-year randomized clinical trial. Int J Oral Maxillofac Implants. 2016 Mar-Apr;31(2):382-90. https://doi.org/10.11607/jomi.4189

40. Huang R, Sun X, Shang Z, Zhang L, Liang X. [Marginal bone loss around tissue level implants in the posterior part of the mandible]. Hua Xi Kou Qiang Yi Xue Za Zhi. 2016 Apr;34(2):145-9. Chinese.

41. Canullo L, Rosa JC, Pinto VS, Francischone CE, Götz W. Inward-inclined implant platform for the amplified platform-switching concept: 18-month follow-up report of a prospective randomized matched-pair controlled trial. Int J Oral Maxillofac Implants. 2012 JulAug;27(4):927-34.

42. Batenburg RH, Meijer HJ, Raghoebar GM, Van Oort RP, Boering G. Mandibular overdentures supported by two Brånemark, IMZ or ITI implants. A prospective comparative preliminary study: one-year results. Clin Oral Implants Res. 1998 Dec;9(6):374-83. https://doi.org/10.1034/j.1600-0501.1996.090603.x

43. Astrand P, Engquist B, Dahlgren S, Engquist E, Feldmann H, Gröndahl K. Astra Tech and Brånemark System implants: a prospective 5-year comparative study. Results after one year. Clin Implant Dent Relat Res. 1999;1(1):17-26. https://doi.org/10.1111/j.1708-8208.1999.tb00087.x

44. Astrand P, Engquist B, Anzén B, Bergendal T, Hallman M, Karlsson U, et al. Nonsubmerged and submerged implants in the treatment of the partially edentulous maxilla. Clin Implant Dent Relat Res. 2002;4(3):115-27. https://doi.org/10.1111/j.1708-8208.2002.tb00161.x

45. Meijer HJ, Batenburg RH, Raghoebar GM, Vissink A. Mandibular overdentures supported by two Brånemark, IMZ or ITI implants: a 5 -year prospective study. J Clin Periodontol. 2004 Jul;31(7):522-6. https://doi.org/10.1111/j.1600-051X.2004.00510.x

46. Arnhart C, Kielbassa AM, Martinez-de Fuentes R, Goldstein M, Jackowski J, Lorenzoni M, et al. Comparison of variable-thread tapered implant designs to a standard tapered implant design after immediate loading. A 3-year multicentre randomised controlled trial. Eur J Oral Implantol. 2012;5(2):123-36.

47. Astrand P, Engquist B, Dahlgren S, Gröndahl K, Engquist E, Feldmann H. Astra Tech and Brånemark system implants: a 5-year prospective study of marginal bone reactions. Clin Oral Implants Res. 2004 Aug;15(4):413-20. https://doi.org/10.1111/j.1600-0501.2004.01028.x

48. Bilhan H, Kutay O, Arat S, Cekici A, Cehreli MC. Astra Tech, Brånemark, and ITI implants in the rehabilitation of partial edentulism: two-year results. Implant Dent. 2010 Oct;19(5):437-46. https://doi.org/10.1097/ID.0b013e3181f57110 
Does the implant-abutment interface interfere on marginal bone loss? A systematic review and meta-analysis

49. Cehreli MC, Uysal S, Akca K. Marginal bone level changes and prosthetic maintenance of mandibular overdentures supported by 2 implants: a 5-year randomized clinical trial. Clin Implant Dent Relat Res. 2010 Jun;12(2):114-21. https://doi.org/10.1111/j.1708-8208.2008.00143.x

50. Koo KT, Lee EJ, Kim JY, Seol YJ, Han JS, Kim TI, et al. The effect of internal versus external abutment connection modes on crestal bone changes around dental implants: a radiographic analysis. J Periodontol. 2012 Sep;83(9):1104-9. https://doi.org/10.1902/jop.2011.110456

51. Meijer HJ, Raghoebar GM, Batenburg RH, Vissink A. Mandibular overdentures supported by two Brånemark, IMZ or ITI implants: a ten-year prospective randomized study. J Clin Periodontol. 2009 Sep;36(9):799-806. https://doi.org/10.1111/j.1600-051X.2009.01442.x

52. Moberg LE, Köndell PÅ, Sagulin GB, Bolin A, Heimdahl A, Gynther GW. Brånemark System and ITI Dental Implant System for treatment of mandibular edentulism. A comparative randomized study: 3-year follow-up. Clin Oral Implants Res. 2001 Oct;12(5):450-61. https://doi.org/10.1034/j.1600-0501.2001.120504.x

53. Pessoa RS, Sousa RM, Pereira LM, Neves FD, Bezerra FJ, Jaecques SV, et al. Bone remodeling around implants with external hexagon and morse-taper connections: a randomized, controlled, split-mouth, clinical trial. Clin Implant Dent Relat Res. 2017 Feb;19(1):97-110. https://doi.org/10.1111/cid.12437

54. Ravald N, Dahlgren S, Teiwik A, Gröndahl K. Long-term evaluation of Astra Tech and Brånemark implants in patients treated with full-arch bridges. Results after 12-15 years. Clin Oral Implants Res. 2013 Oct;24(10):1144-51. https://doi.org/10.1111/j.1600-0501.2012.02524.x

55. Alghamdi HS, Jansen JA. Bone regeneration associated with nontherapeutic and therapeutic surface coatings for dental implants in osteoporosis. Tissue Eng Part B Rev. 2013 Jun;19(3):233-53.https://doi.org/10.1089/ten.teb.2012.0400

56. Baj A, Bolzoni A, Russillo A, Lauritano D, Palmieri A, Cura F, et al. Cone-morse implant connection system significantly reduces bacterial leakage between implant and abutment: an in vitro study. J Biol Regul Homeost Agents. 2017 Apr-Jun;31(2 Suppl 1):203-8.

57. Ganeles J, Wismeijer D. Early and immediately restored and loaded dental implants for single-tooth and partial-arch applications. Int J Oral Maxillofac Implants. 2004;19 Suppl:92-102.

58. Esposito M, Siormpas K, Mitsias M, Bechara S, Trullenque-Eriksson A, Pistilli R. Immediate, early (6 weeks) and delayed loading (3 months) of single implants: 4-month post-loading from a multicenter pragmatic randomised controlled trial. Eur J Oral Implantol. 2016;9(3):249-60.

59. Sugiura T, Yamamoto K, Horita S, Murakami K, Tsutsumi S, Kirita T. The effects of bone density and crestal cortical bone thickness on micromotion and peri-implant bone strain distribution in an immediately loaded implant: a nonlinear finite element analysis. J Periodontal Implant Sci. 2016 Jun;46(3):152-65. https://doi.org/10.5051/ipis.2016.46.3.152

60. Caricasulo R, Malchiodi L, Ghensi P, Fantozzi G, Cucchi A. The influence of implant-abutment connection to peri-implant bone loss: A systematic review and meta-analysis. Clin Implant Dent Relat Res. 2018 Aug;20(4):653-64. https://doi.org/10.1111/cid.12620

61. Lemos CA, Verri FR, Bonfante EA, Santiago Júnior JF, Pellizzer EP. Comparison of external and internal implant-abutment connections for implant supported prostheses. A systematic review and meta-analysis. J Dent. 2018 Mar;70:14-22. https://doi.org/10.1016/i.jdent.2017.12.001

62. Galindo-Moreno P, Fernández-Jiménez A, O’Valle F, Monje A, Silvestre FJ, Juodzbalys G, et al. Influence of the crown-implant connection on the preservation of peri-implant bone: a retrospective multifactorial analysis. Int J Oral Maxillofac Implants. 2015 Mar-Apr;30(2):384-90. https://doi.org/10.11607/jomi.3804

63. Lazzara RJ, Porter SS. Platform switching: a new concept in implant dentistry for controlling postrestorative crestal bone levels. Int J Periodontics Restorative Dent. 2006 Feb;26(1):9-17.

64. Fickl S, Zuhr O, Stein JM, Hürzeler MB. Peri-implant bone level around implants with platform-switched abutments. Int J Oral Maxillofac Implants. 2010 May-Jun;25(3):577-81.

65. Valles C, Rodríguez-Ciurana X, Clementini M, Baglivo M, Paniagua B, Nart J. Influence of subcrestal implant placement compared with equicrestal position on the peri-implant hard and soft tissues around platform-switched implants: a systematic review and meta-analysis. Clin Oral Investig. 2018 Mar;22(2):555-70. https://doi.org/10.1007/s00784-017-2301-1

66. Misch CE. Implant design considerations for the posterior regions of the mouth. Implant Dent. 1999;8(4):376-86. https://doi.org/10.1097/00008505-199904000-00008

67. Zhao G, Schwartz Z, Wieland M, Rupp F, Geis-Gerstorfer J, Cochran DL, et al. High surface energy enhances cell response to titanium substrate microstructure. J Biomed Mater Res A. 2005 Jul;74(1):49-58. https://doi.org/10.1002/jbm.a.30320

68. Huang Y, He J, Gan L, Liu X, Wu Y, Wu F, et al. Osteoconductivity and osteoinductivity of porous hydroxyapatite coatings deposited by liquid precursor plasma spraying: in vivo biological response study. Biomed Mater. 2014 Nov;9(6):065007. https://doi.org/10.1088/1748-6041/9/6/065007

69. Babuska V, Palan J, Kolaja Dobra J, Kulda V, Duchek M, Cerny J, et al. Proliferation of osteoblasts on laser-modified nanostructured titanium surfaces. Materials (Basel). 2018 Sep 26;11(10):pii1827. https://doi.org/10.3390/ma11101827 
Rosa EC, Deliberador TM, Nascimento TCL, Kintopp CCA, Orsi JSR, Wambier LM, et al.

70. Al-Nsour MM, Chan HL, Wang HL. Effect of the platform-switching technique on preservation of peri-implant marginal bone: a systematic review. Int J Oral Maxillofac Implants. 2012 Jan-Feb;27(1):138-45. https://doi.org/10.11607/jomi.5140

71. Santiago JF Jr, Batista VE, Verri FR, Honório HM, de Mello CC, Almeida DA, et al. Platform-switching implants and bone preservation: a systematic review and meta-analysis. Int J Oral Maxillofac Surg. 2016 Mar;45(3):332-45. https://doi.org/10.1016/i.ijom.2015.11.009

72. Alqutaibi AY, Aboalrejal AN. Microgap and micromotion at the implant abutment interface cause marginal bone loss around dental implant but more evidence is needed. J Evid Based Dent Pract. 2018 Jun;18(2):171-2. Available from: https://doi.org/1010.1016/i.jebdp.2018.03.009https://doi.org/10.1016/i.jebdp.2018.03.009

73. Lopes de Chaves E Mello Dias EC, Sperandio M, Napimoga MH. Association between implant-abutment microgap and implant circularity to bacterial leakage: an in vitro study using tapered connection implants. Int J Oral Maxillofac Implants. 2018 May/ Jun;33(3):505-11. https://doi.org/10.11607/jomi.5836

74. Weber HP, Sukotjo C. Does the type of implant prosthesis affect outcomes in the partially edentulous patient? Int J Oral Maxillofac Implants. 2007;22 Suppl:140-72.

75. Shi JY, Jie-Ni, Zhuang LF, Zhang XM, Fan LF, Lai HC. Peri-implant conditions and marginal bone loss around cemented and screw-retained single implant crowns in posterior regions: a retrospective cohort study with up to 4 years follow-up. 2018 Feb 5;13(2):e0191717. https://doi.org/10.1371/journal.pone.0191717.

76. Esmaeli F, Shirmohammadi A, Faramarzie M, Abolfazli N, Rasouli H, Fallahi S. Determination of vertical interproximal bone loss topography: correlation between indirect digital radiographic measurement and clinical measurement. Iran J Radiol. 2012 Jun;9(2):83-7. https://doi.org/10.5812/iraniradiol.7732

77. Jaju PP, Jaju SP. Clinical utility of dental cone-beam computed tomography: current perspectives. Clin Cosmet Investig Dent. 2014 Apr;6:29-43. https://doi.org/10.2147/CCIDE.S41621 